\title{
Analysis of knockout mice suggests a role for VGF in the control of fat storage and energy expenditure
} Elizabeth Watson ${ }^{\dagger 1}$, Samira Fargali ${ }^{\dagger 1}$, Haruka Okamoto ${ }^{2}$, Masato Sadahiro1, Ronald E Gordon ${ }^{3}$, Tandra Chakraborty ${ }^{1,4}$, Mark W Sleeman ${ }^{2}$ and Stephen R Salton*1,5

Address: ${ }^{1}$ Department of Neuroscience, Mount Sinai School of Medicine, New York, NY, USA, ${ }^{2}$ Regeneron Pharmaceuticals Inc., Tarrytown, NY, USA, ${ }^{3}$ Department of Pathology, Mount Sinai School of Medicine, New York, NY, USA, ${ }^{4}$ Biology Department, Adelphi University, Garden City, NY, USA and ${ }^{5}$ Department of Geriatrics, Mount Sinai School of Medicine, New York, NY, USA

Email: Elizabeth Watson - ew2258@columbia.edu; Samira Fargali - samira.fargali@mssm.edu; Haruka Okamoto - haruka.okamoto@regeneron.com; Masato Sadahiro - masato.sadahiro@mssm.edu; Ronald E Gordon - ronald.gordon@mssm.edu; Tandra Chakraborty - chakraborty@adelphi.edu; Mark W Sleeman - mark.sleeman@regeneron.com; Stephen R Salton* - stephen.salton@mssm.edu

* Corresponding author †Equal contributors

Published: 28 October 2009

BMC Physiology 2009, 9:19 doi:10.1 186/1472-6793-9-19
Received: 27 August 2009

Accepted: 28 October 2009

This article is available from: http://www.biomedcentral.com/1472-6793/9/19

(c) 2009 Watson et al; licensee BioMed Central Ltd.

This is an Open Access article distributed under the terms of the Creative Commons Attribution License (http://creativecommons.org/licenses/by/2.0), which permits unrestricted use, distribution, and reproduction in any medium, provided the original work is properly cited.

\begin{abstract}
Background: Previous studies of mixed background mice have demonstrated that targeted deletion of $V g f$ produces a lean, hypermetabolic mouse that is resistant to diet-, lesion-, and genetically-induced obesity. To investigate potential mechanism(s) and site(s) of action of VGF, a neuronal and endocrine secreted protein and neuropeptide precursor, we further analyzed the metabolic phenotypes of two independent VGF knockout lines on C57B16 backgrounds.

Results: Unlike hyperactive VGF knockout mice on a mixed C57B16-129/SvJ background, homozygous mutant mice on a C57Bl6 background were hypermetabolic with similar locomotor activity levels to $\mathrm{Vgf+}$ Vgft mice, during day and night cycles, indicating that mechanism(s) other than hyperactivity were responsible for their increased energy expenditure. In Vgf-/Vgf- knockout mice, morphological analysis of brown and white adipose tissues (BAT and WAT) indicated decreased fat storage in both tissues, and decreased adipocyte perimeter and area in WAT. Changes in gene expression measured by real-time RTPCR were consistent with increased fatty acid oxidation and uptake in BAT, and increased lipolysis, decreased lipogenesis, and brown adipocyte differentiation in WAT, suggesting that increased sympathetic nervous system activity in Vgf-/Vgf- mice may be associated with or responsible for alterations in energy expenditure and fat storage. In addition, uncoupling protein I (UCPI) and UCP2 protein levels, mitochondrial number, and mitochondrial cristae density were upregulated in Vgf-/Vgf- BAT. Using immunohistochemical and histochemical techniques, we detected VGF in nerve fibers innervating BAT and $V g f$ promoter-driven reporter expression in cervical and thoracic spinal ganglia that project to and innervate the chest wall and tissues including BAT. Moreover, VGF peptide levels were quantified by radioimmunoassay in BAT, and were found to be down-regulated by a high fat diet. Lastly, despite being hypermetabolic, VGF knockout mice were cold intolerant.
\end{abstract}

Conclusion: We propose that VGF and/or VGF-derived peptides modulate sympathetic outflow pathways to regulate fat storage and energy expenditure. 


\section{Background}

The sympathetic nervous system (SNS) plays an important role in the regulation of glucose and fat metabolism, and its dysfunction could predispose to obesity and type 2 diabetes mellitus. Mice with defective signaling in the melanocortin pathway, including those that fail to express the hypothalamic melanocortin 4 receptor (MC4R) or its agonist alpha-melanocyte stimulating hormone ( $\alpha$ $\mathrm{MSH}$ ), and those that over-express the MC4R antagonists agouti or agouti-related protein (AGRP or ART), all develop late onset obesity and insulin resistance [1]. The MC4R is expressed in the hypothalamic paraventricular nucleus (PVN), which contains neurons that innervate parasympathetic and sympathetic preganglionic cells in the brainstem and spinal cord, and throughout the brain in sympathetic circuits that innervate brown adipose tissue (BAT) $[2,3]$. These projections give the hypothalamus direct input to the autonomic nervous system, controlling glucose and energy homeostasis [4,5]. The central melanocortin system has therefore been proposed to modulate autonomic outflow and food intake [6,7] through its effects on sympathetic activity to inhibit pancreatic insulin secretion and increase energy utilization $[8,9]$.

Brown and white adipose tissues (BAT and WAT) are sites where humoral factors (e.g. leptin and adiponectin) are synthesized and afferent nerve signals generated, which together convey the state of energy storage to the hypothalamus. These signals contribute to the adaptive responses that occur following changes in the environment, including diet and cold. BAT is the primary site of thermogenesis in rodents and newborn humans, is richly innervated by the SNS, and adipocytes are densely packed with mitochondria that contribute to energy generation and heat dissipation. The thermogenic capacity of BAT is primarily due to uncoupling protein 1 (UCP1) on the inner mitochondrial membrane that uncouples the respiratory chain from ATP generation, producing heat [10]. Norepineprine (NE), released from sympathetic nerve endings, stimulates lipolysis in WAT and increases UCP1 gene expression in BAT; these responses to a high fat diet or cold exposure are controlled at least in part by the central melanocortin system $[3,11]$. Increased UCP1 expression in WAT, the result of SNS stimulation or genetic background, is associated with brown adipocyte induction in WAT depots, and leads to reversal of diet-induced and genetic obesity [1216]. Taken together, these data argue for an important role of the SNS in the control of energy expenditure via outflow to both white and brown adipose tissues.

We have previously reported suppression of obesity, hyperinsulinemia and hyperglycemia in $\mathrm{A} / \mathrm{a}$ agouti and melanocortin 4 receptor deficient (MC4R-/MC4R-) mice by targeted deletion of the $V g f$ gene $[17,18]$. VGF is a secreted protein and peptide precursor that is expressed throughout the brain, in neurons, and in several neuroendocrine and endocrine tissues $[19,20]$. Mice with a targeted deletion of $V g f$ are lean and hypermetabolic, and resist developing obesity and diabetes [21]. Neonatal treatment of $V g f-/ V g f$ - mice with monosodium glutamate, which damages the hypothalamus and the hypothalamic projections to the autonomic nervous system [22-24], blocks the development of the lean phenotype $[17,18]$. This suggests that VGF could regulate energy balance by reducing sympathetic outflow pathway activity to peripheral tissues. To gain insight into the molecular and cellular changes that may be responsible for the increase in energy expenditure and decrease in adipose stores detected in VGF knockout mice, we examined the effect that targeted ablation of VGF has on the regulation of gene expression in adipose tissues, analyzing two independent VGF knockout mouse lines on C57Bl6 backgrounds. We noted alterations in the expression of genes encoding enzymes that control fat synthesis and breakdown, consistent with increased SNS activity. We further found that VGF was expressed in neural pathways innervating BAT, quantified VGF-derived peptides in BAT by RIA, and demonstrated increased UCP1 and UCP2 levels in VGF knockout BAT that were associated with alterations in mitochondrial number and morphology. Our studies support the hypothesis that VGF modulates sympathetic outflow pathway activity to control fat storage and energy expenditure.

\section{Results \\ Metabolic rates are higher, fat and lean body mass lower, and activity levels similar in Vgf-/Vgf- compared to $\mathbf{~ g f + l}$ Vgf+ mice on a C57B16 background}

Previous studies of VGF knockout mice on a mixed C57Bl6-129/SvJ background (designated VGF Mixed $_{\text {knock- }}$ out and abbreviated $\mathrm{VGF}_{\mathrm{M}}$ knockout or $V g f_{M^{-}} /$-) indicated that mice with the $V g f$ gene ablated were hyperactive and hypermetabolic. To investigate whether background strain had an effect on metabolic phenotype, we analyzed the same line of VGF knockout mice that had been backcrossed $\geq 10$ generations to obtain a homogeneous $\mathrm{C} 57 \mathrm{Bl} 6$ background (designated $\mathrm{VGF}_{\mathrm{C} 57}$ knockout or $\left.V g f_{C 57}-/-\right)$, as well as the $\mathrm{F} 3$ generation of an independent mouse line, generated by Regeneron Pharmaceuticals Inc. using F1H4 ES cells (a 129B6/F1-derived cell line), also primarily on a C57Bl6 background ( $>83 \%$ C57Bl6 background; designated $\mathrm{VGF}_{\mathrm{R}}$ knockout or $\left.\mathrm{Vgf}_{R}-/-\right)$ [25]. Similar results were obtained using both of these VGF mutant mouse lines on C57Bl6 backgrounds. As shown in Figure 1 , metabolic rates remained high in homozygous $\mathrm{VGF}_{\mathrm{R}}$ knockout mice, with basal metabolic rate (BMR), defined as oxygen consumption $\left(\mathrm{VO}_{2}\right)$ during the light rest period, significantly elevated ( $\mathrm{p}<0.001$; two tailed $t$-test) in VGF null compared to wild-type littermates. Locomotor activ- 
ity levels and food intake were indistinguishable between control mice and either $\mathrm{VGF}_{\mathrm{R}}$ (Figure 1) or $\mathrm{VGF}_{\mathrm{C} 57}$ (data not shown) knockout mice. Body weight and length were reduced in $\mathrm{VGF}_{\mathrm{R}}$ and $\mathrm{VGF}_{\mathrm{C} 57}$ knockout mice [Figure 2 and [18], respectively], and body mass analysis indicated a reduction in fat and lean mass (Figure 2A-C). Consistent with reduced fat and lean mass, low leptin levels, and the hypothesized increase in sympathetic tone in VGF mutant mice, significant reductions in both bone density and bone mineralization were also noted in $\mathrm{VGF}_{\mathrm{R}}$ knockout mice (Figure 2E-F). Serum chemistries revealed significant reductions in HDL, triglyceride, albumin, and leptin in $\mathrm{VGF}_{\mathrm{R}}$ knockout mice, while total cholesterol, total protein, insulin, LDL, creatinine, magnesium, urea, and uric acid were not significantly different between knockout and wild type mice on the C57Bl6 background (Table 1).

\section{Morphological changes in BAT and WAT of homozygous VGF mutant mice suggest an increase in lipolysis and FA oxidation}

Histological examinations of adipose tissues in $V g f-/$ - and wild type mice were performed to gain insight into which tissues may be responsible for increased energy expenditure and/or decreased fat stores. We compared tissues from $V g f_{R}-/-,-/+$, and +/+ mice, although previous studies have not demonstrated significant metabolic differences between wild type and heterozygous VGF knockout mice $[17,18,21]$. Because fat mass is significantly reduced in $V g f_{C 57}$ and $V g f_{R}-/$ - mice (e.g. Figure 2), certain fat depots were extremely difficult to identify and quantify on the C57Bl6 background, including visceral mesenteric fat, subcutaneous abdominal fat, and retroperitoneal fat. Even though these various fat depots are differentially responsive to a number of stimuli (e.g. diet), and are thought to make specific contributions to glucose and

Table I: Serum measures in wild type $\left(V g f_{R}+/+\right)$ and VGF knockout $\left(V g f_{R}-/-\right)$ mice.

\begin{tabular}{|c|c|c|c|}
\hline & $V g f_{R}+/+$ & $V g f_{R}-/-$ & $P$ value \\
\hline Insulin (ng/mL) & $0.82 \pm 0.14$ & $0.67 \pm 0.19$ & 0.55 \\
\hline Leptin (pg/mL) & $235 I \pm 546$ & $399 \pm 80$ & $0.003 *$ \\
\hline Albumin (g/dL) & $3.02 \pm 0.07$ & $2.74 \pm 0.04$ & $0.0 I^{*}$ \\
\hline Total Protein $(\mathrm{g} / \mathrm{dL})$ & $5.24 \pm 0.12$ & $4.98 \pm 0.09$ & 0.10 \\
\hline Creatinine $(\mathrm{mg} / \mathrm{dL})$ & $0.43 \pm 0.02$ & $0.39 \pm 0.01$ & 0.09 \\
\hline Magnesium (mg/dL) & $2.43 \pm 0.08$ & $2.33 \pm 0.07$ & 0.35 \\
\hline Triglyceride (mg/dL) & $80.29 \pm 9.31$ & $46.03 \pm 3.24$ & $0.003 *$ \\
\hline Urea (mg/dL) & $20.94 \pm 0.99$ & $20.45 \pm 0.62$ & 0.68 \\
\hline Uric Acid (mg/dL) & $1.41 \pm 0.14$ & $1.50 \pm 0.17$ & 0.69 \\
\hline Cholesterol (mg/dL) & $90.25 \pm 5.86$ & $76.18 \pm 3.37$ & 0.06 \\
\hline $\operatorname{LDL}(\mathrm{mg} / \mathrm{dL})$ & $4.36 \pm 0.57$ & $5.21 \pm 0.57$ & 0.31 \\
\hline HDL (mg/dL) & $53.33 \pm 4.80$ & $40.20 \pm 2.05$ & $0.02^{*}$ \\
\hline
\end{tabular}

Chemistry analyses were carried out on serum samples as previously described [103]. Data are expressed as mean \pm SEM; $n=8$ for each genotype. $P$ values of less than 0.05 were considered significant and are denoted by the *. metabolic homeostasis [26], we chose to focus on epididymal WAT and interscapular BAT pads for histological and gene expression analyses because they could be reproducibly isolated from knockout mice. BAT and WAT have distinct physiological roles in maintaining energy homeostasis; BAT is the most highly metabolic and innervated tissue in rodents, while WAT is the principal site of adipose storage. The BAT of $V g f_{C 57}-/-, V g f_{R}-/-, V g f_{R}+/-$, and wild type mice was comprised of typical multilocular cells, however, these cells in VGF knockout mice contained large numbers of smaller lipid droplets, suggesting that the tissue remained metabolically active (Figure 3DF; quantification panel G; Additional file 1: Supplemental Figure 1). Moreover, the WAT depot that normally surrounds BAT in wild type mice was absent in $V g f-/$ - mice (see Additional files 1 and 2: Supplemental Figures 1 and 2). WAT from $V g f-/-$ mice contained less stored lipid in comparison to wild type mice (Figure 3, C and 3A), consistent with the body composition fat mass analysis (Figure 2). Morphometric analysis indicated that mean adipocyte area was significantly reduced in knockout WAT (Figure $3 \mathrm{H}$ ), which was associated with a shift in the distribution of adipocytes favoring those with smaller perimeters (Figure 3I). In general, quantitative analysis of WAT and BAT demonstrated that heterozygous $\mathrm{VGF}_{\mathrm{R}}$ knockout mice had an intermediate phenotype between wild type and homozygous knockout mice (Figure $3 \mathrm{G}$ and $3 \mathrm{H}$ ). Overall, H\&E analysis of $V g f_{C 57}-/-$ BAT and WAT (Additional file 1: Supplemental Figure 1) revealed a similar pattern of histological staining to that obtained with the respective $V g f_{R}-/$ - tissues (Figure 3 ).

\section{Vgf-/Vgf- mice have altered adipose mRNA levels encoding proteins involved in the regulation of energy storage, fatty acid utilization, and sympathetic nervous system activity}

The adipose tissues of $\mathrm{VGF}_{\mathrm{C} 57}$ and $\mathrm{VGF}_{\mathrm{R}}$ mutant mice were morphologically different from wild type mice. To understand the molecular mechanisms responsible for decreased fat stores in epididymal WAT and interscapular BAT, we carried out an extensive analysis of gene expression in these $\mathrm{VGF}_{\mathrm{C} 57}$ tissues using real-time RT-PCR. In WAT, the levels of mRNAs, encoding enzymes responsible for building fat stores, acetyl coA carboxylase (ACC), glycerol-3-phosphate acyltransferse (GPAT) and diacylglycerol acyltransferase (DGAT), were unaltered in Vgf -/mice, while an increase in mRNA levels encoding hormone sensitive lipase (HSL), an enzyme responsible for lipolysis which mobilizes fat, was found in $V g f-/-$ mice. Gene expression of peroxisome-proliferator activated receptor gamma (PPAR $\gamma)$, a protein that promotes adipocyte differentiation, and sterol regulatory element binding protein 1C (SREBP-C1), which activates genes responsible for lipogenesis and glucose utilization [27], were decreased in VGF knockout WAT. RNA levels encoding fatty acid synthase (FAS), an enzyme that synthesizes 

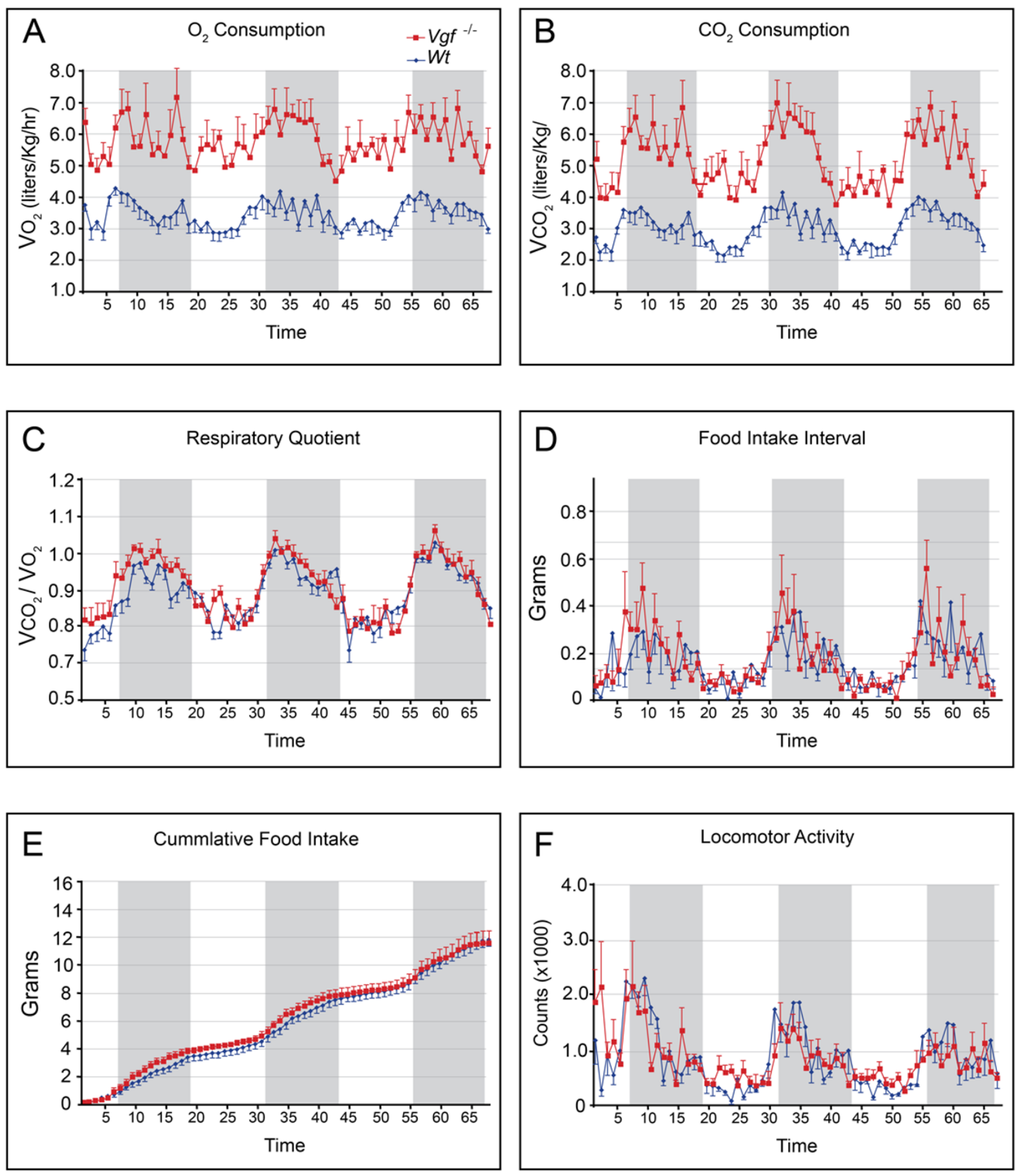

\section{Figure I}

VGF-deficient mice on a C57BI6 background are hypermetabolic, with normal food intake and locomotor activity. Metabolic cage analysis revealed that $\mathrm{Vg} \mathrm{f}_{\mathrm{R}}-/$ - mice have significantly increased $\mathrm{O}_{2}\left(\mathrm{VO}_{2}\right.$, panel $\left.\mathrm{A}\right)$ and $\mathrm{CO}_{2}\left(\mathrm{VCO}_{2}\right.$, panel B) consumption (two-tailed $t$-test; $\mathrm{p} \leq 0.05$ ), while respiratory quotient (panel $\mathrm{C}$ ), food intake (panels $\mathrm{D}$ and $\mathrm{E}$ ) and locomotor activity (panel $F$ ) were similar to wild type littermates $(n=7-8$ mice of each genotype). Alternating white and grey shaded regions in panels E-F represent light rest and dark active periods, respectively. 

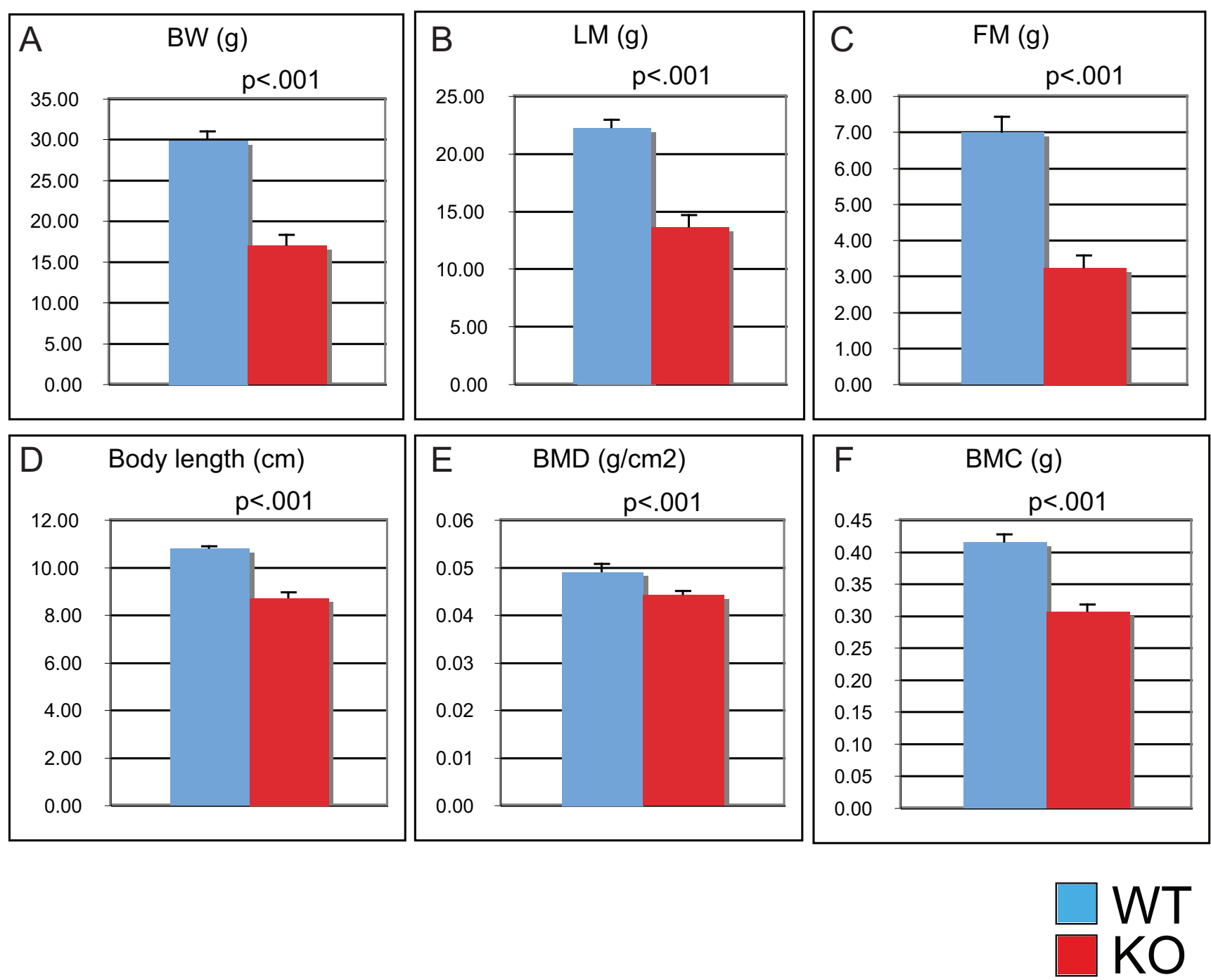

Figure 2

VGF-deficient mice on a C57BI6 background have decreased fat and lean body mass, and decreased bone mineral density and content. Body weight (Panel A) (grams), body composition (Panels B and C) [lean mass (LM) and fat mass (FM)] (grams), length (Panel D) (cm), bone mineral density (BMD) (Panel E) $\left(\mathrm{g} / \mathrm{cm}^{2}\right)$ and bone mineral content (BMC) (Panel F) (grams), were determined in $\mathrm{VGF}_{R}$ mice using dual emission $\mathrm{x}$-ray absorption. Data are expressed as mean $\pm \mathrm{SEM}(\mathrm{n}=7-8$ male mice of each genotype per group).

fatty acids from acetyl COA and malonyl COA, however, was elevated in Vgf-/- WAT. In VGF knockout BAT, levels of mRNAs encoding the lipogenic proteins ACC, GPAT and PPAR $\gamma$ were increased (Table 2).

Next we looked at gene products responsible for fatty acid beta-oxidation in these tissues. RNA levels of proteins responsible for fatty acid and glucose uptake, lipoprotein lipase (LPL) and glucose 4 transporter (GLUT 4), and translocation of fatty acids to the mitochondria, carnitine palmitoyltransferase 1 (CPT1), were up regulated in Vgf /- BAT, whereas LPL and GLUT4 gene expression were down regulated and CPT1 mRNA levels unaltered in WAT.
PPAR $\alpha$ is thought to play an important role in lipid metabolism, and mRNA levels were increased in VGF knockout BAT and WAT. Furthermore, mRNA levels encoding PPAR $\gamma$ coactivator 1 (PGC-1), a co-activator of nuclear receptors that increases metabolism by stimulating mitochondrial biogenesis and respiration, were upregulated in BAT and WAT of the $V g f_{C 57}-/$ - mutant mouse, and a concomitant increase in cytochrome $\mathrm{C}$ oxidase II (COX II) mRNA levels was also found (Table 3).

We then investigated whether altered BAT morphology could be associated with an increase in thermogenesis by examining mRNA levels for the uncoupling proteins. 

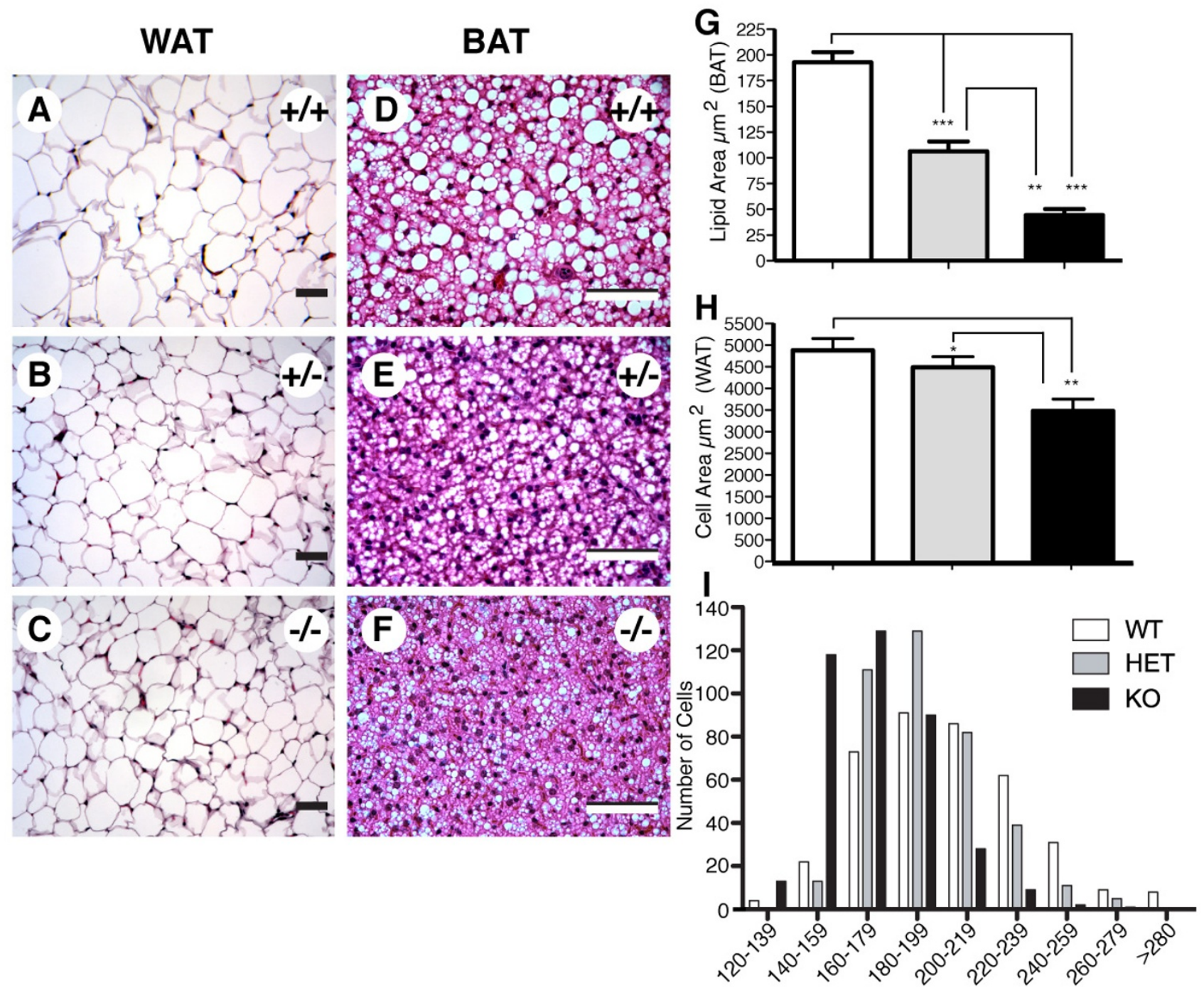

Cell Perimeter $\mu$ m (WAT)

Figure 3

Lipid deposition in multilocular cells of brown adipose tissue (BAT) and unilocular cells of white adipose tissue (WAT) is reduced in VGF knockout mice. Representative sections of epididymal WAT (A-C) and interscapular BAT (DF) from ad lib-fed, age-matched $\operatorname{Vg} f_{R}+/+(A, D),+/-(B, E)$ and -/- (C, F) were stained with H\&E. Adipocytes in interscapular BAT and epididymal WAT from -/- mice (C and F) contain less lipid accumulation than the corresponding adipocytes from wild type mice $(A$ and $D)$. Scale bars are $50 \mu \mathrm{m}$ in length. Morphometric analysis of adipose tissue from $V g f_{R}+/+,+/-$, and $-/-$ mice was carried out using MetaMorph, as detailed in Materials and Methods. Lipid area in BAT (panel G), cell area in WAT (panel H), and the distribution of adipocyte perimeters in WAT (panel I), were quantified for each genotype. Note the significant reduction in lipid area in both +/- and -/- BAT (ANOVA, F $(2,15)=73.5, \mathrm{p}<0.0001$ ), significant reduction in adipocyte area in -/WAT (ANOVA, $F(2,15)=7.6, p=0.005)$, and shift in the distribution of cells favoring those with significantly smaller perimeters in -/- and +/- WAT (comparison of mean perimeters in $\mu \mathrm{m}$; ANOVA, $F(2,1 \mathrm{I} 67)=166, \mathrm{p}<0.000 \mathrm{I}$ ), compared to wild type. Values are mean \pm SEM, ${ }^{*} p<0.05$, ${ }^{*} p=0.005$, $*^{* *} *_{p}<0.0001$ compared to wild type (ANOVA and Bonferroni's posthoc test). 
Table 2: Expression of genes in epididymal WAT and interscapular BAT that contribute to lipolysis or lipogenesis in VGF knockout and wild type mice.

\begin{tabular}{|c|c|c|c|c|c|c|}
\hline Tissue & Gene & $\begin{array}{l}\text { Mean Cycle Threshold }\left(C_{t}\right) \\
\text { Value }\end{array}$ & Std. Error & $\begin{array}{l}\text { Fold Difference in mRNA Levels } \\
\left(2^{\Delta \Delta C t}\right)\end{array}$ & $\begin{array}{l}\text { P- } \\
\text { Value }\end{array}$ & $\begin{array}{l}\text { RNA Levels in VGF } \\
-/- \text { vs }+/+ \text { mice }\end{array}$ \\
\hline BAT & $A C C$ & $\begin{array}{l}\text { Vgf//Vf- } 2.57 \\
\text { Vgf+/Vgf+ } 1.52\end{array}$ & $\begin{array}{l}.596 \\
.205\end{array}$ & 2.1 & NS & \\
\hline BAT & DGAT & $\begin{array}{l}V g f / V g f-3.45 \\
V g f+/ V g f+3.52\end{array}$ & $\begin{array}{l}.210 \\
.092\end{array}$ & 1.0 & NS & \\
\hline BAT & GPAT & $\begin{array}{l}V g f / V g f-6.95 \\
V g f+/ V g f+8.12\end{array}$ & $\begin{array}{l}.253 \\
.127\end{array}$ & 2.3 & .0060 & Increased \\
\hline BAT & PPAR $\gamma$ & $\begin{array}{l}V g f / V g f-.633 \\
V g f+/ V g f+1.73\end{array}$ & $\begin{array}{l}.285 \\
.239\end{array}$ & 2.1 & .002 & Increased \\
\hline WAT & ACC & $\begin{array}{l}\text { Vgf/Vgf- } 5.20 \\
\text { Vgf+/Vgf+ } 3.39\end{array}$ & $\begin{array}{l}.517 \\
.333\end{array}$ & 3.5 & .001 & Decreased \\
\hline WAT & DGAT & $\begin{array}{l}\text { Vgf/Vgf- } 6.88 \\
\text { Vgf+/Vgf+ } 7.88\end{array}$ & $\begin{array}{l}.370 \\
.525\end{array}$ & 2.0 & NS & \\
\hline WAT & GPAT & $\begin{array}{l}\text { Vgf-/Vgf- } 7.83 \\
\text { Vgf+/Vgf+ } 9.01\end{array}$ & $\begin{array}{l}.458 \\
1.13\end{array}$ & 2.2 & NS & \\
\hline WAT & $\operatorname{PPAR} \gamma$ & $\begin{array}{l}V g f / V g f-4.75 \\
V g f+/ V g f+3.60\end{array}$ & $\begin{array}{l}.315 \\
.138\end{array}$ & 2.2 & .010 & Decreased \\
\hline WAT & FAS & $\begin{array}{l}V g f / V g f-2.45 \\
V g f+/ V g f+4.80\end{array}$ & $\begin{array}{l}.193 \\
.227\end{array}$ & 5.1 & .0098 & Increased \\
\hline WAT & SREBPIC & $\begin{array}{l}V g f / V g f-12.6 \\
V g f+/ V g f+8.99\end{array}$ & $\begin{array}{l}.953 \\
.560\end{array}$ & 12.1 & .001 & Decreased \\
\hline WAT & HSL & $\begin{array}{l}V g f / V g f-7.79 \\
V g f+/ V g f+11.6\end{array}$ & $\begin{array}{l}.405 \\
1.10\end{array}$ & 14.0 & .022 & Increased \\
\hline
\end{tabular}

Real time RT-PCR analysis was carried out in quadruplicate as described in the Methods. The fold difference was calculated from the indicated mean cycle threshold $\left(C_{t}\right)$ values, the amplification cycle when product can first be detected: lower $C_{t}$ values correspond to greater abundance. $C_{t}$ values were normalized to the expression of the housekeeping gene beta-actin $(\Delta \Delta \mathrm{Ct})$, and fold difference in mRNA calculated as $2 \Delta \Delta \mathrm{Ct}$, as detailed in Methods, with $\mathrm{p} \leq 0.05$ considered significant.

Uncoupling Protein 1 (UCP1) by disrupting the proton gradient across the inner mitochondrial membrane is crucial for non-shivering thermogenesis, leading to heat production (reviewed in [28-30]). UCP2 and UCP3 also regulate proton conductance, however they require activation by reactive oxygen species, and may protect against oxidative damage (reviewed in [28-30]). In addition, UCP3 may transport fatty acids, while UCP2 may attenuate insulin secretion in pancreatic beta cells. In $\mathrm{VGF}_{\mathrm{C} 57}$ knockout mice compared to wild type mice, we noted that mRNA levels of UCP1 were lower in BAT, but the mRNA levels of UCP2 and UCP3 were increased (Table 4). Notably, in WAT, levels of UCP1 mRNA were robustly increased in $V g f-/$ - mice (Table 4).

Lastly, we looked at genes indicative of sympathetic nervous system (SNS) activity. The SNS-mediated physiologi- cal responses, FA oxidation and lipolysis, mostly rely on release of norepinephrine from the post-ganglionic neurons which binds to beta-3-adrenergic receptors ( $\beta 3 \mathrm{AR}$ ) on the adipocyte's cell surface, as well as to the other beta receptors, $\beta 1 \mathrm{AR}$ and $\beta 2 \mathrm{AR}$. Mice with decreased sympathetic activity due to leptin deficiency have a 300-fold reduction in $\beta 3 A R$ mRNA in comparison to lean animals $[31,32]$. Therefore we looked at the mRNA levels of the beta-adrenergic receptors to provide indirect support for an increase in SNS tone in VGF mutant mice. In BAT, B3AR mRNAs were increased in VGF knockout mice in comparison to wild type mice. In WAT, however, the gene expression of $\beta 2 A R$ was significantly higher in $V g f-/$ - mice than $V g f+/+$ mice, while $\beta 3 \mathrm{AR}$ mRNA levels were similar (Table 5). 
Table 3: Expression of genes in epididymal WAT and interscapular BAT that contribute to fatty acid oxidation in VGF knockout and wild type mice.

\begin{tabular}{|c|c|c|c|c|c|c|}
\hline Tissue & Gene & Mean Cycle Threshold $\left(C_{t}\right)$ Value & $\begin{array}{l}\text { Std. } \\
\text { Error }\end{array}$ & $\begin{array}{l}\text { Fold Difference in mRNA Levels } \\
\left(2^{\Delta \Delta C t}\right)\end{array}$ & P-Value & $\begin{array}{l}\text { RNA Levels in } \text { VGF }_{\text {C57 }} \\
-/- \text { vs }+/+ \text { mice }\end{array}$ \\
\hline BAT & PPAR $\alpha$ & $\begin{array}{l}V g f-/ V g f-5.23 \\
V g f+/ V g f+5.83\end{array}$ & $\begin{array}{l}.433 \\
.222\end{array}$ & 1.5 & NS & \\
\hline BAT & LPL & $\begin{array}{l}V g f-/ V g f-2.33 \\
V g f+/ V g f+3.48\end{array}$ & $\begin{array}{l}.259 \\
.263\end{array}$ & 2.2 & .021 & Increased \\
\hline BAT & CPT-I & $\begin{array}{l}V g f / V g f-13.9 \\
V g f+/ V g f+15.3\end{array}$ & $\begin{array}{l}.546 \\
.312\end{array}$ & 2.6 & .05 & Increased \\
\hline WAT & PGC-I & $\begin{array}{l}V g f-/ V g f-10.1 \\
V g f+/ V g f+12.2\end{array}$ & $\begin{array}{l}.431 \\
.271\end{array}$ & 4.3 & .0028 & Increased \\
\hline WAT & cox॥ & $\begin{array}{l}V g f-/ V g f-1.91 \\
V g f+/ V g f+2.67\end{array}$ & $\begin{array}{l}.207 \\
.048\end{array}$ & 1.7 & .019 & Increased \\
\hline WAT & PPAR $\alpha$ & $\begin{array}{l}V g f-/ V g f-11.9 \\
V g f+/ V g f+14.3\end{array}$ & $\begin{array}{l}.494 . \\
.112\end{array}$ & 5.3 & .0069 & Increased \\
\hline WAT & LPL & $\begin{array}{l}V g f-/ V g f-4.09 \\
V g f+/ V g f+0.96\end{array}$ & $\begin{array}{l}1.13 \\
.111\end{array}$ & 2.0 & .0232 & Decreased \\
\hline WAT & CPT-I & $\begin{array}{l}V g f-/ V g f-16.3 \\
V g f+/ V g f+16.7\end{array}$ & $\begin{array}{l}.543 \\
.427\end{array}$ & 1.3 & NS & \\
\hline
\end{tabular}

Real time RT-PCR analysis was carried out in quadruplicate as described in the Methods. The fold difference was calculated from the indicated mean cycle threshold $\left(C_{t}\right)$ values, the amplification cycle when product can first be detected: lower $C_{t}$ values correspond to greater abundance. $C_{t}$ values were normalized to the expression of the housekeeping gene beta-actin $(\Delta \Delta \mathrm{Ct})$, and fold difference in mRNA calculated as $2 \Delta \Delta \mathrm{Ct}$, as detailed in Methods, with $\mathrm{p} \leq 0.05$ considered significant.

Western and electron microscopic analyses indicate that UCPI and UCP2 protein levels and mitochondrial number are upregulated in VGF knockout BAT

To determine the basis of the hypermetabolic state in VGF knockout mice, given the somewhat surprising lack of an increase in UCP1 mRNA levels in BAT (Table 4), we exam- ined protein levels of UCPs in BAT by western analysis, and quantified mitochondrial size and number, and cristae density, by electron microscopy. UCP1 and UCP2 protein levels were significantly increased in BAT from $V g f_{R}-/$ - knockout compared to wild type mice (Figure 4, panels $\mathrm{A}$ and $\mathrm{B} ; \mathrm{p}<0.05, \mathrm{ANOVA})$. To determine whether mito-

Table 4: Expression of genes in epididymal WAT and interscapular BAT that contribute to thermogenesis in VGF knockout and wild type mice.

\begin{tabular}{|c|c|c|c|c|c|c|}
\hline Tissue & Gene & Mean Cycle Threshold $\left(C_{t}\right)$ Value & $\begin{array}{l}\text { Std. } \\
\text { Error }\end{array}$ & $\begin{array}{l}\text { Fold Difference in mRNA Levels } \\
\left(2^{\Delta \Delta C t}\right)\end{array}$ & P-Value & $\begin{array}{l}\text { RNA Levels in VGF } \\
-/- \text { vs }+/+ \text { mice }\end{array}$ \\
\hline BAT & UCPI & $\begin{array}{l}V g f / / V f-3.53 \\
V g f+/ V g f+1.22\end{array}$ & $\begin{array}{l}.843 \\
.272\end{array}$ & 4.9 & .024 & Decreased \\
\hline BAT & UCP2 & $\begin{array}{l}V g f-/ V g f-1.88 \\
V g f+/ V g f+4.15\end{array}$ & $\begin{array}{l}.259 \\
.233\end{array}$ & 4.8 & .0013 & Increased \\
\hline WAT & UCPI & $\begin{array}{l}V g f / V g f-11.2 \\
V g f+/ V g f+14.4\end{array}$ & $\begin{array}{l}.433 \\
.527\end{array}$ & 9.2 & .0031 & Increased \\
\hline WAT & UCP2 & $\begin{array}{l}V g f-/ V g f-3.02 \\
V g f+/ V g f+3.86\end{array}$ & $\begin{array}{l}.535 \\
.275\end{array}$ & 1.8 & .025 & Increased \\
\hline
\end{tabular}

Real time RT-PCR analysis was carried out in quadruplicate as described in the Methods. The fold difference was calculated from the indicated mean cycle threshold $\left(C_{t}\right)$ values, the amplification cycle when product can first be detected: lower $C_{t}$ values correspond to greater abundance. $C_{t}$ values were normalized to the expression of the housekeeping gene beta-actin $(\Delta \Delta \mathrm{Ct})$, and fold difference in mRNA calculated as $2 \Delta \Delta \mathrm{Ct}$, as detailed in Methods, with $\mathrm{p} \leq 0.05$ considered significant. 
Table 5: Expression of genes in epididymal WAT and interscapular BAT that contribute to sympathetic nervous system activity in VGF knockout and wild type mice.

\begin{tabular}{|c|c|c|c|c|c|c|}
\hline Tissue & Gene & Mean Cycle Threshold $\left(C_{t}\right)$ Value & $\begin{array}{l}\text { Std. } \\
\text { Error }\end{array}$ & $\begin{array}{l}\text { Fold Difference in mRNA Levels } \\
\left(2^{\Delta \Delta C t}\right)\end{array}$ & P-Value & $\begin{array}{l}\text { RNA Levels in } \text { VGF }_{\text {C57 }} \\
-/- \text { vs }+/+ \text { mice }\end{array}$ \\
\hline BAT & $\beta 3 A R$ & $\begin{array}{l}V g f-/ V g f-2.55 \\
V g f+/ V g f+2.90\end{array}$ & $\begin{array}{l}.456 \\
.461\end{array}$ & 1.3 & NS & \\
\hline BAT & $\beta 2 A R$ & $\begin{array}{l}V g f-/ V g f-4.50 \\
V g f+/ V g f+7.54\end{array}$ & $\begin{array}{l}.730 \\
.204\end{array}$ & 8.0 & .0029 & Increased \\
\hline BAT & $\beta I A R$ & $\begin{array}{l}V g f-/ V g f-8.41 \\
V g f+/ V g f+8.13\end{array}$ & $\begin{array}{l}.222 \\
.193\end{array}$ & 1.2 & NS & \\
\hline WAT & $\beta 3 A R$ & $\begin{array}{l}V g f / / g f-2.35 \\
V g f+/ V g f+1.37\end{array}$ & $\begin{array}{l}.750 \\
.278\end{array}$ & 1.9 & NS & \\
\hline WAT & $\beta 2 A R$ & $\begin{array}{l}V g f / V g f-5.71 \\
V g f+/ V g f+7.21\end{array}$ & $\begin{array}{l}.361 \\
.192\end{array}$ & 2.8 & .0104 & Increased \\
\hline WAT & $\beta I A R$ & $\begin{array}{l}\text { Vgf-/Vgf- } 4.43 \\
V g f+/ V g f+5.45\end{array}$ & $\begin{array}{l}.634 \\
.143\end{array}$ & 2.0 & NS & \\
\hline
\end{tabular}

Real time RT-PCR analysis was carried out in quadruplicate as described in the Methods. The fold difference was calculated from the indicated mean cycle threshold $\left(C_{t}\right)$ values, the amplification cycle when product can first be detected: lower $C_{t}$ values correspond to greater abundance. $C_{t}$ values were normalized to the expression of the housekeeping gene beta-actin $(\Delta \Delta \mathrm{C} t)$, and fold difference in mRNA calculated as $2^{\Delta \Delta C_{t}}$, as detailed in Methods, with $p \leq 0.05$ considered significant.

chondrial biogenesis could be affected by germline $V g f$ ablation, knockout and wild type BAT was examined by electron microscopy (Figure 4, panels C-E and F-H, respectively). Mitochondrial number was increased (Figure 4I), mitochondrial area decreased (Figure 4J), and cristae density increased (Figure 4K), in VGF -/- knockout compared to +/+ wild type mice.

\section{VGF immunoreactivity can be detected in BAT and VGF- derived AQEE30 peptide levels are regulated by diet}

BAT is a highly metabolic tissue that is innervated by noradrenergic sympathetic fibers, which also contain other neuropeptides such as NPY [33-37]. As previous studies suggested that VGF ablation could potentially impact sympathetic nervous system activity to peripheral metabolic tissues such as fat, and for technical reasons immunohistochemical visualization of VGF in WAT was difficult, we investigated whether VGF was expressed in nerve fibers that innervate BAT. We first quantified the level of VGF-derived C-terminal peptides by subjecting acid extracts of BAT to a sensitive radioimmunoassay (RIA) that has been previously described [38]. This RIA utilizes a polyclonal antibody specific for the VGF-derived C-terminal peptide AQEE30 (VGF peptides are designated by the four N-terminal amino acids and length), so detects AQEE30 and the N-terminally extended peptides that contain this sequence, TLQP62 and NAPP129 [38]. Immunoreactive AQEE30 was detected in BAT, and was found to be downregulated when $\mathrm{C} 57 \mathrm{Bl} 6$ mice were fed a high fat diet for two weeks (Figure 5A). Parenchymal nerve fibers make direct contact with adipocytes, activating them via beta-adrenergic receptors, or are associated with finely branched vessels that penetrate the tissue but do not make direct contacts with the adipocytes $[39,40]$. By immunofluorescence and immunohistochemistry, anti-VGF staining was found in BAT to abut adipocytes and was also seen in the periarterial plexus (Additional file 3: Supplemental Figure 3, panels A, C, D), similar to the distribution reported for anti-tyrosine hydroxylase (Additional file 3: Supplemental Figure 3, panel B), which binds the rate-limiting enzyme in catecholamine biosynthesis and is a marker of catecholaminergic nerves and terminals [37]. Consistent with finding VGF in nerve fibers and terminals that innervate BAT, we were also able to indirectly localize $V g f$ gene expression in spinal ganglia and intercostal nerves of heterozygous knockout mice. Intercostal nerves, which contain autonomic and sensory fibers that innervate BAT [41] and additional structures including the skin and musculature of the chest and abdomen, and the dorsal root ganglia, which give rise to the somatic and sensory afferents in the intercostal nerve, were found to express $\beta$-galactosidase from the lac $Z$ reporter gene that was knocked into the mouse $V g f$ locus

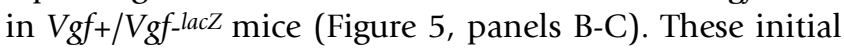
data suggest that VGF and/or VGF-derived peptides could be released from neurons that innervate adipose tissues, as is NPY [42-44], and that VGF AQEE30 peptide levels in BAT are regulated by diet; additional studies will be required to determine whether adipocytes synthesize 
A

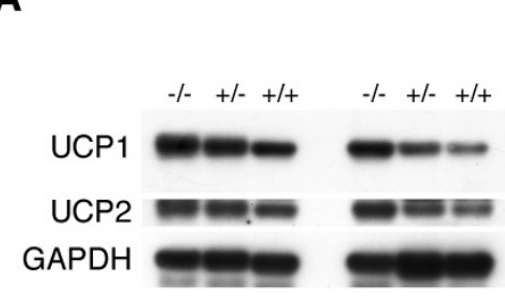

B

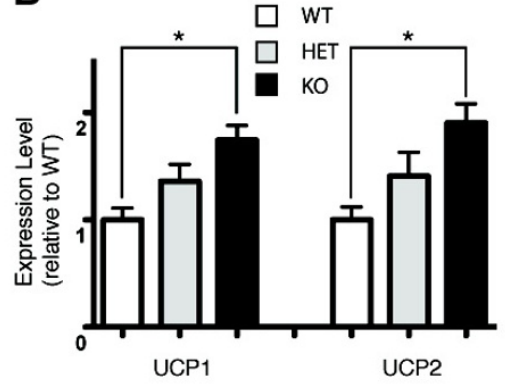

C

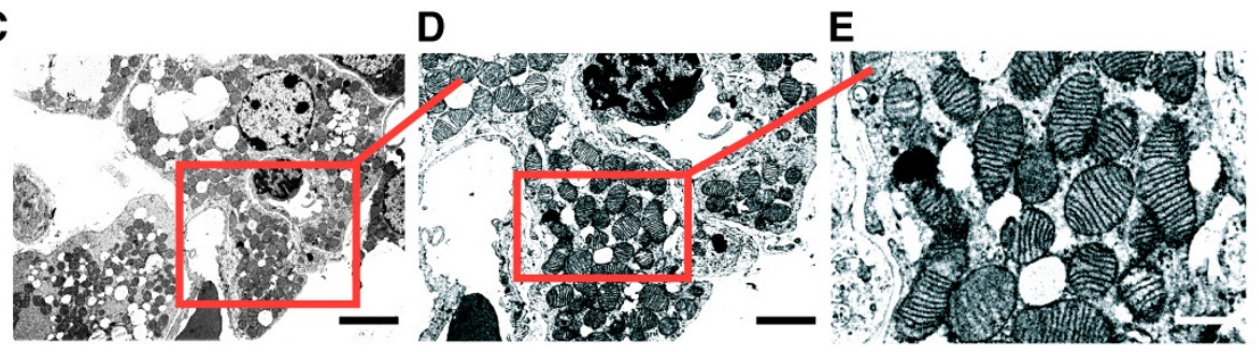

$\mathbf{F}$

G

H

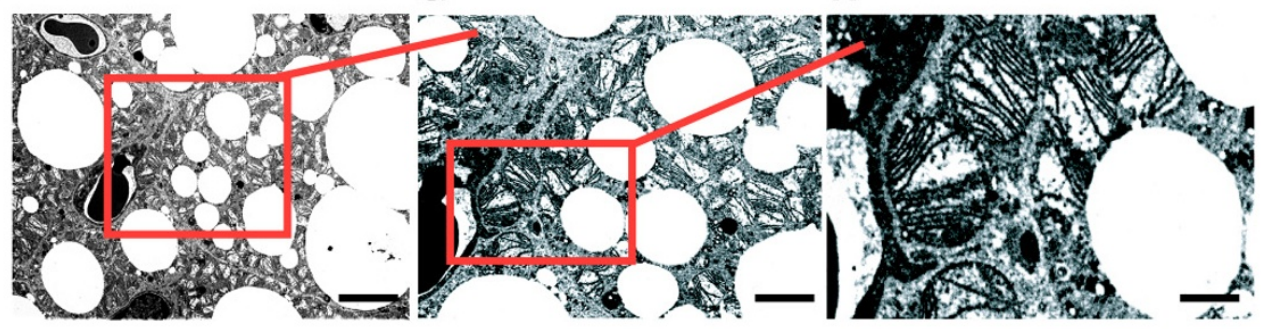

I

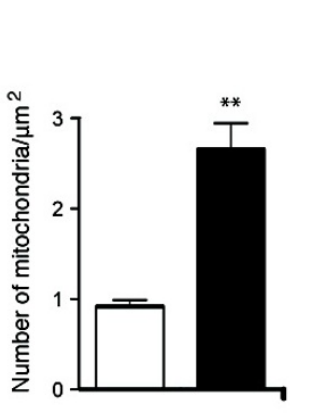

J

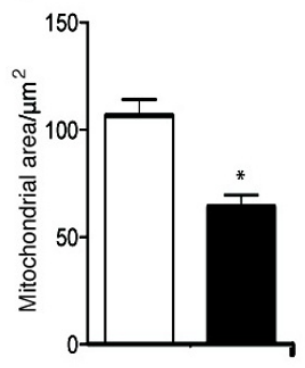

K

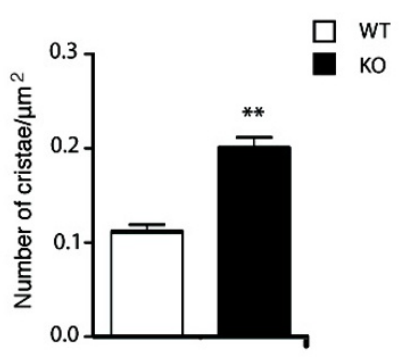

Figure 4

VGF ablation affects UCPI \& UCP2 protein expression, mitochondrial morphology, and mitochondrial number in BAT. Representative western blots of UCPI, UCP2, and GAPDH protein levels in BAT from Vgf $+/+,+/-$, and $-/-$ mice (panel A), and densitometric quantification by NIH image (panel B). Comparable results were found in at least three additional experiments. Ablation of VGF significantly increased UCPI and UCP2 levels in BAT from Vgf $f_{R}-/-$ but not $V g f_{R}+/-$ mice compared to wild type +/+ mice $[n=5$ mice per group, mean \pm SEM, F $(2, I 2)=4.35(\mathrm{UCPI}), \mathrm{F}(2, \mathrm{I} 2)=3.33(\mathrm{UCP} 2)$, *P $<$ 0.05 , ANOVA and Dunnett's posthoc test]. Representative electron microscope photomicrographs of BAT from Vgf $f_{R} /-($ panels $\mathrm{C}-\mathrm{E}$ ) and $+/+$ mice (panels F-H) are shown. The part of the image that is boxed in red is shown at higher magnification in the panel to its immediate right. Scale bars are $5 \mu \mathrm{m}$ (panels $C$ and F), $2.5 \mu \mathrm{m}$ (panels D and G), and I.25 $\mu \mathrm{m}$ (panels E and H).

Note that mitochondria are smaller and more numerous in $V g f_{R}-/-$ in comparison to $+/+$ BAT (compare panels $E$ and $H$ ), which is quantified in panels $\mathrm{I}$ and $\mathrm{J}$. In panel $\mathrm{K}$, the number of cristae per $\mu \mathrm{m}^{2}$ of mitochondrial area was quantified in $V g f_{R}-/-$ and $+/+$ BAT. Values are mean \pm SEM; ${ }^{* * *}$ p $=0.0002$ (panel E), ${ }^{* *} p=0.00$ I (panel F), ${ }^{* * *} p<0.000$ I (panel G) (Student's t-test). 
VGF, analogous to recent reports that they produce NPY $[45,46]$.

\section{VGF knockout mice are extremely sensitive to acute cold stress}

In rodents, the principal functions of BAT are to generate heat during cold exposure so as to maintain body temperature (cold-induced thermogenesis), and to dissipate excess energy in response to dietary intake (diet-induced thermogenesis). To determine whether VGF ablation affected BAT function and thermogenesis, $V g f_{C 57}-/-$ and $V g f_{\mathrm{C} 57}+/+$ mice were acutely exposed to the cold. In contrast to wild type mice that were able to maintain body temperature, VGF knockout mice despite being hypermetabolic rapidly became hypothermic at $4{ }^{\circ} \mathrm{C}$ (Figure 6).

\section{Discussion}

In this study, we investigated the effect that targeted ablation of VGF has on peripheral adiposity, and the possible mechanism(s) by which this neuronal, endocrine, and neuroendocrine secreted polypeptide might regulate fat storage and autonomic homeostasis. VGF mutant mice on a C57Bl6 background are hypermetabolic and lean, with reduced lean and fat mass, despite normal food consumption and locomotor activity levels (Figures 1 and 2). These current findings are consistent with previous studies of VGF mutant mice on a mixed C57Bl6/sv129 background [21]. Thus, serum chemistries, insulin-tolerance, glucosetolerance, metabolic measurements, and body composition are all very similar among VGF knockout mice on mixed (designated $\mathrm{VGF}_{\mathrm{M}}$ ), homogeneous $\mathrm{C} 57 \mathrm{Bl} 6$ (designated $\mathrm{VGF}_{\mathrm{C} 57}$ ), or $~ 83 \% \mathrm{C} 57 \mathrm{Bl} 6$ backgrounds (designated $\left.\operatorname{VGF}_{R}\right)[17,18]$ and this report], with the notable exception that VGF knockout mice on a C57Bl6 background $\left(\mathrm{VGF}_{\mathrm{R}}\right.$ and $\mathrm{VGF}_{\mathrm{C} 57}$ ) are not hyperactive (Figure 1 and data not shown), and thus locomotor activity cannot play a substantive role in their increased energy expenditure.

Could increased sympathetic tone or sensitivity to norepinephrine be responsible for alterations in adipose morphology and the expression of critical gene products? Decreased lipid accumulation in WAT, smaller interscapular WAT depots that are associated with BAT, and regions of fat accretion in BAT, are consistent with increased sympathetic nervous system activity. In addition, changes in gene expression in WAT and BAT correlate with these morphological differences, as does body composition analysis. Activation of the sympathetic nervous system promotes catabolism by increasing glucose and fatty acid uptake into BAT [47], and by increasing lipolysis in WAT. Hormone sensitive lipase (HSL) is induced by sympathetic activity [48], is up-regulated by fasting in most adipose depots except subcutaneous fat [49-51], and both HSL mRNA and protein levels in adipose tissue are decreased in the obese insulin-resistant state [52]. Of note, HSL was one of the most robustly up-regulated genes in WAT from $V g f_{\mathrm{C} 57}-/$ - mice (Table 2). Although lipoprotein lipase (LPL) activity is generally regulated at the post-transcriptional level in adipose tissues (e.g. [53]), allowing rapid responses to alterations in diet, LPL mRNA levels correlate with PPAR $\gamma$ mRNA levels in epididymal WAT [54] and increase with PPAR $\gamma$ agonist treatment [55], likely due to a transcriptionally active PPAR response element upstream of the LPL gene [56]. Small but significant decreases in LPL mRNA and PPAR $\gamma$ mRNAs were noted in WAT from VGF knockout mice, while small increases in both mRNA levels were measured in BAT. Increased LPL expression in BAT has previously been described in mice exposed to cold or injected with norepinephrine [57], so the increased LPL expression we measured in $\mathrm{VGF}_{\mathrm{C} 57}$ knockout BAT may reflect increased sympathetic pathway activity. Decreased fat stores could result from continuous breakdown of triglycerides into fatty acids, which is associated with increased fatty acid synthase (FAS) mRNA levels in WAT and higher circulating FFA levels previously noted in Vgf-/Vgf-mice on a C57Bl6 background [18]. We further noted increases in cytochrome c oxidase II, PPAR $\alpha$, PGC1, UCP1, and UCP2 mRNA levels in WAT from VGF knockout mice. The PGC1 coactivators play essential roles in BAT differentiation, mitochondrial biogenesis, and thermogenesis [58], so increased expression of PGC1 could drive alterations in WAT morphology and UCP1 gene expression towards a 'brown fat' phenotype in $V g f_{C 57}$ -/- mice.

Previous studies indicate that induction of UCP1 levels in the absence of increased adrenergic activity does not necessarily lead to increased UCP1 activity and thermogenesis $[59,60]$. Conversely, the thermogenic capacity of BAT can be augmented without an associated increase in sympathetic activity, as noted in the Syrian hamster exposed to a short photoperiod or fed a high-energy diet, where increased thermogenesis occurs in the absence of changes in norepinephrine turnover [61-63]. Our metabolic studies of VGF mutant mice consistently demonstrate increased $\mathrm{O}_{2}$ consumption irrespective of genetic background ([21] and this report), and together with the current analysis of gene expression, would be most consistent with increased fatty acid oxidation and decreased lipogenesis in adipose tissues, and possibly also thermogenic activity due to enhanced UCP1 levels in WAT, which could be associated with increased adrenergic activity. In BAT, targeted ablation of VGF resulted in increased UCP1 protein levels, increased mitochondrial number, and increased cristae number per square micron of mitochondrial area, suggesting increased sympathetic activity, but did not increase cold tolerance. Cold intolerance (Figure 6) in VGF mutants could be a result of lack of available fuel, as in the adlib fed state, these mice have reduced fat depots and display a fasted phenotype, with little detecta- 

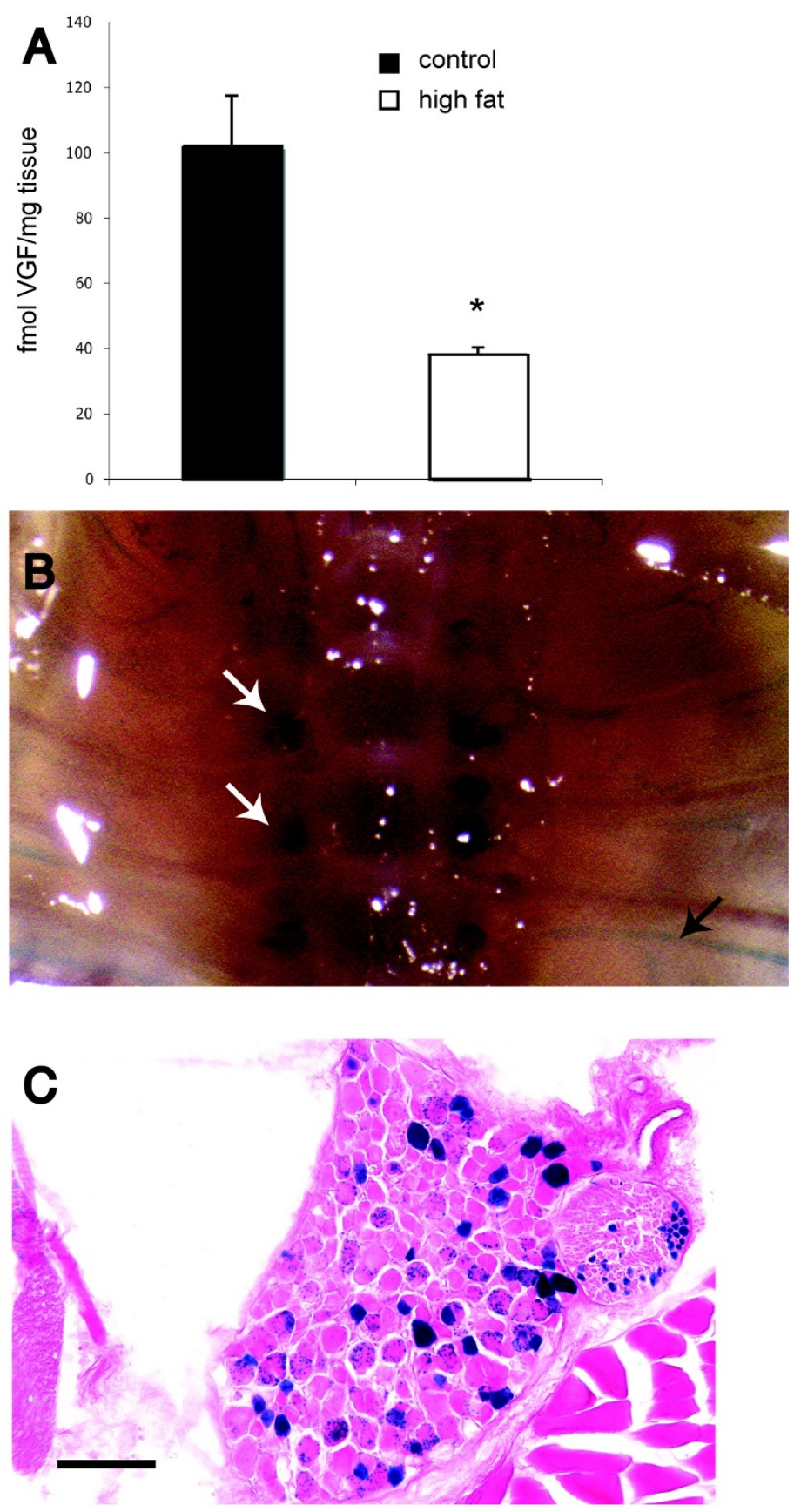

Figure 5

VGF is expressed in neural pathways that innervate brown adipose tissue (BAT). In panel A, levels of VGF-derived peptides were quantified in BAT from C57BI6 female mice fed standard chow or a high fat, high carbohydrate diet for I4 days. BAT was removed and RIA analysis carried out to quantify C-terminal VGF-derived peptides (NAPPI29, TLQP62 and AQEE30, but not full length VGF), using polyclonal anti-AQEE30 (VGF $\left.{ }_{588-617}\right)$ antiserum as previously described [38]. VGF peptide levels in BAT were significantly reduced in mice fed the high-energy diet in comparison to control mice ( $p<0.05)$. Comparisons by ANOVA [mean \pm SEM; high fat diet $(n=4)$, standard diet $(n=3)$ ]. In panels B-C, Vgf gene expression was visualized in neural pathways that innervate tissues including BAT using a lacZ reporter gene that was knocked into the mouse $\mathrm{Vgf}$ locus in $\mathrm{VGF}_{\mathrm{R}}$ mice (see Methods). In panel B, $\beta$-galactosidase expression (blue staining) in the dorsal root ganglia (white arrows) and intercostal nerve (black arrow) is seen in a whole mount preparation from a heterozygous $V g f_{R}+/-$ mouse. A dorsal root ganglion section is shown at higher magnification in panel C (scale bar is $100 \mu \mathrm{m}$ in length). 
ble liver glycogen, low circulating glucose levels, increased circulating FFA, elevated hypothalamic NPY and AGRP mRNA levels, and decreased hypothalamic POMC mRNA levels $[17,18,21]$. Alternatively, sympathetic outflow to various adipose depots could differ, as has been demonstrated for specific WAT pads during prolonged fasting and following leptin administration [64,65].

Neonatal monosodium glutamate (MSG) blocks the development of the lean phenotype in $\mathrm{VGF}_{\mathrm{M}}$ knockout mice [17], suggesting that increased SNS activity is associated with increased fat oxidation and energy expenditure in homozygous $V g f-/ V g f$ - mice. Neonatal guanethidine treatment, which creates a generalized chemical sympathectomy, also blocked the development of the lean phenotype in $\mathrm{VGF}_{\mathrm{C} 57}$ knockout mice, and increased circulating glucose levels (see Additional file 2: Supplemental Figure 2), but was not sufficiently well-tolerated by VGF knockout mice to carry out a complete analysis of its effects. These experiments are consistent with the realtime PCR data, and a role for increased sympathetic pathway activity in mice that lack VGF. Although we were unable to study the developing SNS in $V g f$ - $V g f$ - P0 newborn pups due to insufficient numbers, we did note that tyrosine hydroxylase (TH) immunostaining in the SNS of
$V g f_{C 57}+/$ - pups was significantly more robust than $V g f_{C 57}$ $+/+$ pups, consistent with a possible increase in SNS catecholamine turnover (E. Watson and S. Salton, unpublished data) [66]. Increased sympathetic tone in the absence of changes in BAT UCP1 gene expression was noted in lean, hypermetabolic $\mathrm{M}_{3}$ muscarinic acetylcholine receptor knockout mice [67], which are very similar to VGF mutant mice in phenotype, and also largely resistant to high fat diet-induced, gold-thio-glucose-induced and genetically $(o b / o b)$-induced obesity, hyperphagia, hyperinsulinemia, and hyperglycemia [17,18,21,67].

Both cold exposure and overeating increase sympathetic drive to BAT to stimulate thermogenesis [68-70]. Are the sympathetic pathways that control increased energy expenditure and decreased fat storage regulated by independent CNS circuits? Adipose-synthesized leptin controls energy balance in part via activation of the SNS [71], regulating body weight and temperature [72-74]; chemical sympathectomy with guanethidine blocks this leptin effect, preventing diet-induced thermogenesis [75]. Leptin regulates functionally divergent hypothalamic MC4Rcontaining pathways to control food intake and energy expenditure [76]. MC4R mRNA has also been localized in sympathetic nervous system outflow neurons that inner-

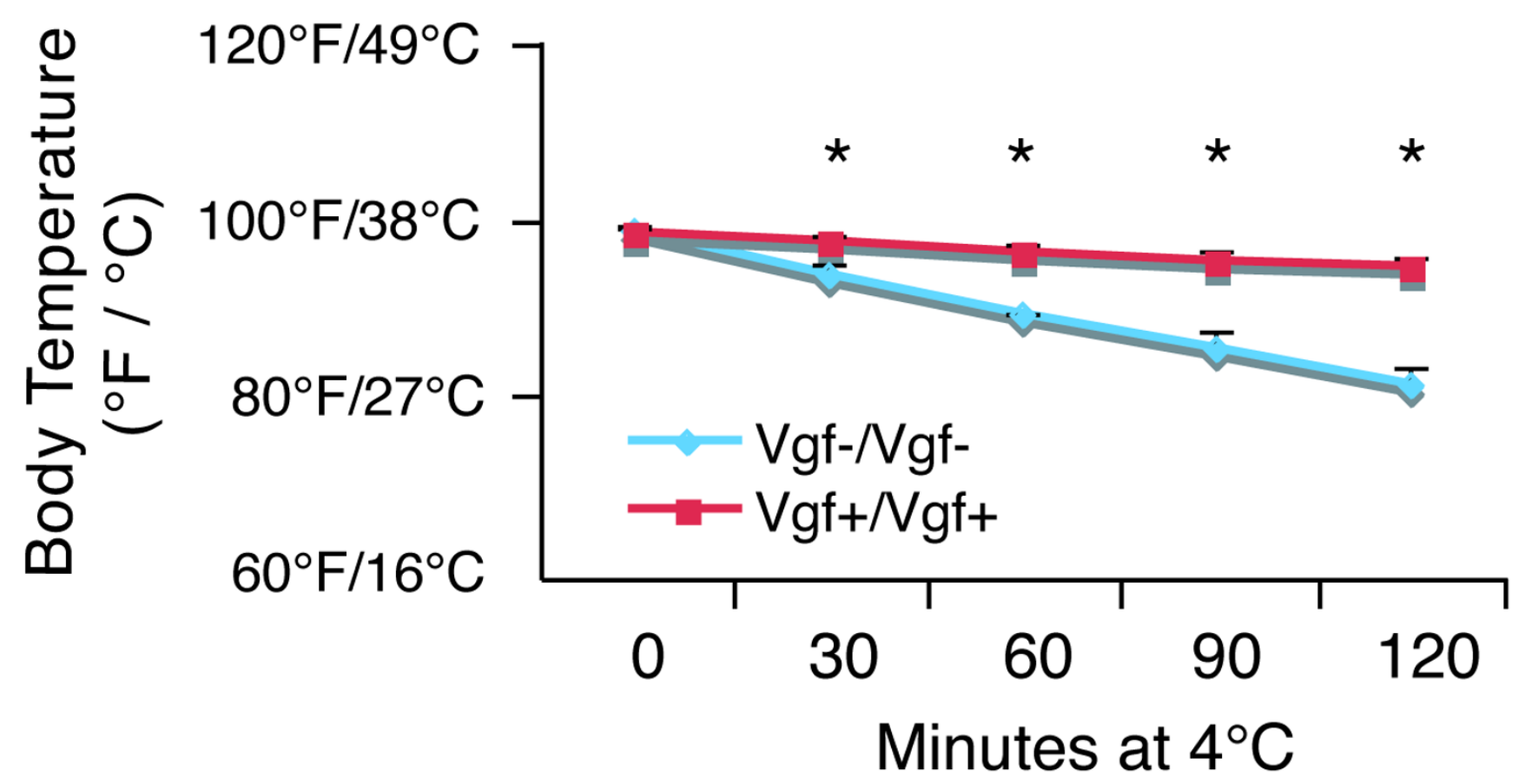

\section{Figure 6}

VGF-deficient mice have increased sensitivity to cold exposure. $V g f_{C 57} /-$ and $V g f_{C 57}+/+$ mice were placed at $4^{\circ} \mathrm{C}$ for 2 hours and allowed adlib access to food and water. Mice were individually housed and rectal temperatures were taken every 30 minutes. Body temperatures that are marked with an asterix from mutant $(n=2)$ and wild-type mice $(n=5)$ are significantly different from each other (ANOVA; $p<0.05$; mean \pm SEM). 
vate WAT [2]. How the CNS and sympathetic outflow circuits coordinately regulate lipid mobilization in WAT and thermogenesis in BAT in response to cold stress and/or diet is not fully understood, but retrograde tract tracing with pseudorabies virus suggests that MC4R-expressing cells in the hypothalamic PVN are positioned to increase sympathetic drive to both WAT and BAT [2]. It is likely, however, that both melanocortin and melanocortin-independent pathways are involved, as MC4R-deficient mice are still able to maintain normal body temperature and thermo-regulate during extended cold exposure [77], but are apparently unable to up-regulate UCP1 in BAT in response to short term cold stress or a high fat diet [3]. VGF ablation blocks obesity, hyperglycemia and hyperinsulinemia in MC4R-deficient mice [18], so this protein may function in these outflow pathways to regulate sympathetic nervous system activity and lipid storage.

Adaptive thermogenesis is mediated primarily via betaadrenergic receptors, and genetic association studies have revealed that the genes encoding these receptors include a large number of coding and non-coding polymorphisms, which have clear functional consequences but less clear contributions to the pathogenesis of obesity, diabetes and hypertension [78]. Mice that lack $\beta 1, \beta 2$ and $\beta 3$ adrenergic receptors ('beta-less' mice) are obese, primarily the result of defective SNS-dependent activation of diet-induced thermogenesis because lipolytic responses to fasting were not altered $[79,80]$. Siberian hamsters have an increase in sympathetic drive during short day exposure, which reduces fat mass $[81,82]$. This increase in SNS activity correlates with an increase in $\beta 3$ receptor mRNA levels in adipose tissues [82], and interestingly, we noted an increase in $\beta 3$ receptor mRNA levels in VGF knockout BAT but not WAT, and increased $\beta 2$ receptor mRNA levels in WAT, perhaps correlating with increased SNS activity [79]. Recent studies indicate that norepinephrine can induce lipolysis in WAT in beta-less mice [83], suggesting a beta-adrenoreceptor independent pathway, and moreover, in the absence of norepinephrine or epinephrine, dopaminebeta-hydroxylase (DBH) knockout mice are not predisposed to obesity, as are beta-less mice, and maintain glucose tolerance [84]. The contribution of betaadrenoreceptors and SNS activity to fat mass is therefore complicated, and notably, leptin-induced decreases in fat mass are not consistently accompanied by increases in norepinephrine (NE) turnover, a measure of SNS activity [65]. Further studies are needed to investigate whether increased HSL gene expression and lipolysis are associated with increased NE turnover in specific fat depots from VGF mutant mice.

Of note, the neuropeptides $\alpha$-MSH and NPY have been demonstrated to increase and decrease lipolysis, respectively, in fully differentiated 3T3-L1 adipocytes [42], so by analogy, direct effects of VGF peptides on adipocytes are also possible, particularly in light of the expression of VGF in BAT (Figure 5) and in the sympathetic nervous system $[85,86]$. We quantified AQEE immunoreactive peptides by RIA in BAT, and noted that levels decrease in response to a high fat diet (HFD). Parallel studies with larger cohorts of $\mathrm{C} 57 \mathrm{Bl} 6$ mice have revealed that $\mathrm{C} 57 \mathrm{Bl} 6$ mice consuming a HFD compared to a chow diet generally increase their energy intake (food consumption in grams is similar) [87], and after 2 weeks, body weight has not changed [87], or has increased by 10\% ([88]; J. Mastaitis and C.V. Mobbs, personal communication and [89]). This alteration in energy balance is sufficient to trigger compensatory changes in gene expression in liver [87], including increased expression of genes involved in fatty acid oxidation. Our data would suggest that VGF C-terminal peptide TLQP62, hypothesized to decrease sympathetic outflow pathway activity to adipose tissues $[17,18]$, is present in BAT and levels decrease as part of the compensatory response to increased energy intake.

Recent experiments have found that 14-day intracerebroventricular (icv) administration of the C-terminal VGFderived peptide TLQP21 (VGF residues 556-576) increases energy expenditure and prevents diet-induced obesity in mice [90], and decreases food intake and body weight in hamsters [91]. Analysis of TLQP21-treated mice revealed a phenotype with numerous additional similarities to VGF knockout mice including increased energy expenditure, increased WAT $\beta 2$-adrenergic receptor mRNA levels, increased WAT UCP1 mRNA levels, normal locomotor activity, and decreased WAT weight s see Results and [21]\}. However, rather than very similar phenotypes, one would anticipate that mice lacking VGF and those chronically treated with VGF-derived TLQP21 peptide would potentially have opposing metabolic phenotypes. Because the precise levels of TLQP21 in brain tissue are not yet known compared to the relatively abundant Cterminal TLQP62 peptide (VGF residues 556-617), one of the major VGF-derived peptides detected in neuronal and endocrine tissues $[38,92,93]$, and different C-terminal peptides derived from TLQP62 have opposing effects on energy balance [94], several alternative mechanisms of action are possible: (1) TLQP21 and TLQP62 could each activate its own receptor with the overall biological effect dependent on the concentration of each peptide and the distribution and affinity of putative receptors, (2) TLQP21 could inhibit actions of full length VGF or longer VGFderived C-terminal peptides, including TLQP62 and NAPP129, which all contain the TLQP21 sequence, and/ or (3) chronic TLQP21 treatment could lead to down-regulation of VGF receptor(s) and signaling. Consistent with mechanism 2, we have recently noted that TLQP21, but not a scrambled peptide, blocks TLQP62-induced electrical potentiation in hippocampal slices [95]. In addition, 
Severini et al. [96] have recently described a role for TLQP21 in cerebellar granule neuron survival and cellular signaling, and in the regulation of gastric motor function [97]. Taken together, these data indicate that specific VGFderived peptides are biologically active, and may signal through independent or shared cell surface receptor(s) to regulate autonomic homeostasis and peripheral adiposity.

\section{Conclusion}

Study of two independent VGF knockout mouse lines indicates that $V g f$ gene products regulate fat storage and energy expenditure through a mechanism that is independent of an effect on locomotor activity. Histological and electron microscopic analysis, coupled with real-time PCR and western analysis, demonstrate physiological and morphological changes in VGF germline knockout mice that are consistent with decreased fat storage, decreased adipocyte area, increased lipolysis, and decreased lipogenesis in WAT, and increased fatty acid oxidation, increased UCP1 and UCP2 protein levels, and increased mitochondrial number and cristae density in BAT. Identification of VGF in BAT, together with these data, supports the hypothesis that VGF and/or VGF-derived peptides modulate sympathetic outflow pathways that regulate adiposity and energy expenditure.

\section{Methods}

\section{Mouse Strains and Diets}

Previously described mice with a targeted deletion of the $\mathrm{V} g f$ gene on a mixed C57Bl/6 and 129/SVJ background (designated $\mathrm{VGF}_{\mathrm{M}}$ or $\mathrm{Vgf}_{\mathrm{M}^{-}} /$-) [21], were repetitively backcrossed 10 generations onto wild type $\mathrm{C} 57 \mathrm{Bl} / 6$ mice (designated $\mathrm{VGF}_{\mathrm{C} 57}$ or $\left.V g f_{\mathrm{C} 57}-/-\right)$, and heterozygous $V g f+/ V g f-$ mice on a homogenous $\mathrm{C} 57 \mathrm{Bl} / 6$ background were mated to generate wild type, heterozygous, and homozygous VGF-deficient mice. A second VGF-deficient line was generated by Regeneron Pharmaceuticals Inc. as previously described [25] using F1H4 ES cells (a 129B6/F1-derived cell line) and a BAC-based targeting vector with deletion of the entire $V g f$ coding sequence and insertion of an in frame lac $Z$ reporter gene and neomycin-selection cassette; chimeric mice resulted from the injection of two independent $V g f-/ V g f$ - embryonic stem cell clones into C57BL6/J blastocysts. Male chimeras were mated with C57BL6/J females to produce F1 breeders and experiments were performed on N2F1 mice (>83\% C57Bl6 background; designated $\mathrm{VGF}_{\mathrm{R}}$ or $V g f_{R^{-}}-$-) from two separate clones with similar results.

Mice were housed at room temperature in a $12 \mathrm{~h}$ light, 12 $\mathrm{h}$ dark cycle, with chow and water available adlib unless otherwise specified. Mice fed standard chow received a $4.5 \%$ fat, $55 \%$ carbohydrate, $20 \%$ protein, $4.7 \%$ fiber diet (Purina PicoLab Rodent Diet 20-5053; 4 Kcal/gm; Purina.
St. Louis, MO). For high fat diet studies, mice received a high fat (33.5-35.5\%) and high simple carbohydrate (34$35.5 \%$ ) diet that also contained $20 \%$ protein and $0.1 \%$ fiber (Bio-Serv F2685; $5.4 \mathrm{kcal} / \mathrm{g}$ ). All animal studies were conducted in accordance with the Guide for Care and Use of Experimental Animals, using protocols approved by Institutional Animal Care and Use Committees at Mount Sinai School of Medicine or Regeneron Pharmaceuticals Inc.

\section{Tissue Preparation and Immunohistochemistry}

Mice were sacrificed and white and brown adipose tissues removed, fixed in formalin and embedded in paraffin. Sections $(5 \mu \mathrm{m})$ were stained with hemotoxylin and eosin. Transcardial perfusions were performed with $4 \%$ paraformaldehyde in PBS after washing in saline solution. After perfusion brown adipose tissue was dissected and fixed overnight in the same fixative and then embedded in paraffin for immunohistochemistry. Polyclonal rabbit antibodies were raised against a VGF (amino acids 8-349)trpE fusion protein [98]. Dewaxed sections $(10 \mu \mathrm{m})$ were processed through the following steps for antigen retrieval: (1) treated with $0.3 \%$ hydrogen peroxide in methanol for 20 minutes; (2) microwaved for 20 minutes in $10 \mathrm{mM}$ citric acid buffer to retrieve antigens; (3) incubated for 48 hours at $4{ }^{\circ} \mathrm{C}$ in PBS that contained $0.3 \%$ Triton $\mathrm{X} 100,3 \%$ normal goat, 3\% horse serum, and antiVGF or anti-tyrosine hydroxylase (Chemicon International, Temecula, CA) antibody (1:50); (4) incubated for 1 hour in biotinylated secondary antibody, goat anti-rabbit IgG (1:200). Staining was performed using an avidin:biotyinylated enzyme complex (vector ABC kit, Vector laboratories, Burlingame, CA) with diaminobenzidine as a substrate. For immunofluorescence, polyclonal rabbit anti-VGF (1:1000) was used to stain BAT. Dewaxed sections $(10 \mu \mathrm{m})$ were subjected to an antigen retrieval step, were incubated overnight at $4{ }^{\circ} \mathrm{C}$ in PBS that contained $0.3 \%$ Triton X100, 3\% normal goat, 3\% horse serum, and VGF antibody (1:50), and lastly with Texas red goat antirabbit 1:250 for 1 hour. Staining was visualized using a Zeiss Axiophot microscope.

\section{Morphometry}

Isolated BAT and WAT were immersed and fixed in formalin, embedded in paraffin, sectioned, and stained with H\&E. Slides were analyzed using Zeiss Axiophot microscope and images captured with a SPOT digital camera. Calculation of mean cell size, lipid area, and cell size distribution was performed using MetaMorph Imaging Software (Molecular Devices, Downingtown, PA). For image analysis, 6 images per group were randomly selected to measure the mean cell size and size distribution in WAT. Groups consisted on 2 mice of each genotype [wild type $\left(V g f_{+} / V g f_{+}\right)$, heterozygous knockout $\left(V g f_{+} / V g f_{-}\right)$, and homozygous knockout $(V g f-/ V g f-)]$, and images were 
taken with $20 \times$ and $10 \times$ objectives for BAT and WAT, respectively. Mean cell size and size distribution were determined from 390 adipocytes in WAT. As it was difficult to outline the cells in BAT because of the accumulation of lipid in the cytoplasm, lipid area in BAT was quantified using MetaMorph Imaging Software.

\section{Electron Microscopy}

For electron microscopic examination, BAT samples were placed in ice-cold fixative buffer (3\% gluteraldehyde in $0.2 \mathrm{M}$ sodium cacodylate buffer $\mathrm{pH} 7.3$ ) for $2 \mathrm{~h}$. Specimens were washed in $0.2 \mathrm{M}$ sodium cacodylate buffer $\mathrm{pH}$ 7.3 for $10 \mathrm{~min}$, postfixed in $1 \%$ osmium tetroxide in 0.2 $\mathrm{M}$ sodium cacodylate buffer for $1 \mathrm{~h}$, washed and dehydrated in graded ethyl alcohol steps, and embedded in pure EPON A\&B mixture with DMP-30. Ultrathin sections for electron microscopy were examined using a Hitachi H7650 instrument linked to an SIA digital camera (Scientific Instruments and Applications, Duluth, GA) controlled by Maxim CCD software. Electron micrographs were obtained at 20,000× magnification, and mitochondrial analysis was carried out using MetaMorph Imaging Software. Six images per group [ 2 mice of each genotype: wild type $\left(V g f_{+} / V g f_{+}\right)$and homozygous knockout $\left.(V g f-/ V g f-)\right]$ were randomly chosen, and the number and the area of mitochondria/ $\mu \mathrm{m}^{2}$ were measured. The mean mitochondrial area $/ \mu \mathrm{m}^{2}$ was determined from 316 mitochondria in BAT. The cristea number was calculated from 40 mitochondria for each group ( 2 images/group).

\section{Western Blot Analysis}

BAT and epididymal WAT from wild type $(V g f+/ V g f+)$, heterozygous knockout $(V g f+/ V g f-)$, and homozygous knockout $(V g f-/ V g f-) \quad(\mathrm{n}=5$ mice for each group) were homogenized in ice cold lysis buffer $[50 \mathrm{mM}$ Tris-HCl (pH 8) $150 \mathrm{mM} \mathrm{NaCl}, 0.02 \%$ sodium azide, $0.1 \%$ SDS, $0.5 \%$ deoxycholate and 1\% NP40] supplemented with protease and phosphatase inhibitor cocktails (Roche Diagnostics, Mannheim, Germany; Thermo Scientific, Waltham, MA). Lysates were cleared by centrifugation $\left(14,000 \mathrm{rpm}, 10 \mathrm{~min}\right.$ at $\left.4^{\circ} \mathrm{C}\right)$, and the protein concentration of the supernatant determined by the BCA protein method (Thermo Scientific). Protein samples $(25 \mu \mathrm{g})$ were separated by SDS-PAGE and transferred to nitrocellulose membranes (Millipore, Bedford, MA). Membranes were blocked with $5 \%(\mathrm{~W} / \mathrm{V})$ BSA in phosphate-buffered saline, and were probed with rabbit polyconal anti-UCP1 [1:1000 (v/v)] (Calbiochem, San Diego CA), rabbit polyconal anti-UCP2 [1:1000 (v/v)] (Calbiochem), or mouse monoclonal anti-GAPDH $[1: 1000(\mathrm{v} / \mathrm{v})]$ (Cell Signaling Technology, Danvers, MA), at $4{ }^{\circ} \mathrm{C}$ overnight. After 3 washes in PBS-T $(0.1 \%$ Tween in PBS) membranes were incubated for 1 hour with HRP-conjugated secondary antibody [1:10,000 (v/v) in PBS-T] (GE Healthcare, Piscataway, NJ) containing 5\% non-fat dry milk. After 3 washes in PBS-T bound antibodies were detected using ECL (Thermo Scientific) and exposure to HyBlot CL (Denville Scientific, Metuchen, NJ). Densitometric quantification was performed using NIH ImageJ.

\section{$\beta$-galactosidase Histology}

For $\beta$-galactosidase staining, mice were deeply anesthetized $(240 \mathrm{mg} / \mathrm{kg}$ ketamine, $48 \mathrm{mg} / \mathrm{kg}$ xylazine i.m.) and exsanguinated with ice-cold heparinized saline. Tissues were fixed by transcardial perfusion of $2 \%$ paraformaldehyde in $0.1 \mathrm{M}$ phosphate buffer, postfixed for $2 \mathrm{hr}$, and then washed in several changes of phosphate-buffered saline. Whole mount staining was then carried out essentially as previously described $[99,100]$, preparations were examined, and then cryoprotected for a least $24 \mathrm{hr}$ in two changes of buffered $30 \%$ sucrose at $4{ }^{\circ} \mathrm{C}$ with agitation before sectioning.

\section{Radioimmunoassay}

Tissues were sonicated and extracted in $0.1 \mathrm{M}$ acetic acid for $6-7 \mathrm{~min}$ at $70^{\circ} \mathrm{C}$ [101]. Homogenates were subjected to centrifugation $\left(14,000 \times \mathrm{g}\right.$ for $\left.30 \mathrm{~min}, 4^{\circ} \mathrm{C}\right)$, and the supernatants were dried using a Speed Vac concentrator (Sorvall) and stored at $-80^{\circ} \mathrm{C}$. Samples were resuspended in $0.1 \mathrm{M} \mathrm{NaHPO}_{4}, 0.1 \%$ TritonX-100, pH 7.2 and subjected to RIA. Rabbit polyclonal antiserum directed against the VGF-derived C-terminal AQEE30 peptide was utilized, and RIAs carried out as previously described [38]. Under these acid extraction conditions, the RIA directed against the C-terminal AQEE30 peptide would also be expected to cross-react with $\mathrm{N}$-terminally extended peptides TLQP62 and NAPP129 in these tissue extracts.

\section{RNA isolation and RT-PCR}

Mice were sacrificed, and brown and white (epididymal fat pads) adipose tissues were removed, flash frozen on dry ice, and stored at $-80^{\circ} \mathrm{C}$ until use. Fat pads were homogenized in Trizol and RNA was extracted according to the manufacturer's instructions (Invitrogen Corporation, Carlsbad, CA). Total RNA (5 $\mu \mathrm{g})$ was reverse transcribed in a $20 \mu \mathrm{l}$ reaction using Superscript II enzyme (Invitrogen Corporation, Carlsbad, CA), and single stranded cDNA was diluted 1:50 for RT-PCR. Using Syber Green Master Mix (Applied Biosystems, Foster City, CA), amplification was performed in ABI Prism 8500 system for 40 cycles in quadruplicate. SDS 2.1 software was used for analyzing cycle threshold $\left(\mathrm{C}_{t}\right)$ values, and expression of the housekeeping gene beta actin was used to normalize levels according to the following formula: $\Delta \Delta \mathrm{Ct}=\left(\mathrm{C}_{\mathrm{t}}\right.$ geneX VGFko - $\mathrm{C}_{\mathrm{t}}$ actin VGFko $)-\left(\mathrm{C}_{\mathrm{t}}\right.$ geneX wild type $-\mathrm{C}_{\mathrm{t}}$ actin wild type). Fold difference in mRNA levels between $V g f-/ V g f-$ and $V g f_{+} / V g f_{+}=2^{\Delta \Delta C t}$. Forward and reverse primers were designed based on published studies and on database analysis as follows: acetyl-CoA carboxylase (ACC), 5'-CAGATCCAGGCCATGTTGAGACG and 3'-TCG 
CTGGGTGGGTGAGATGTG; beta-1-adrenergic receptor ( $\beta 1 \mathrm{AR}), 5^{\prime}$-CGGCTGCAGACGCTCACCAA and 3'-CGCCA CCAGTGCATGAGGAT; beta-2-adrenergic receptor ( $\beta 2 A R), 5$ '-GCTGCAGAAGATAGACAAAT and 3'-GGGAT CCTCACACAGCAGTT; beta-3-adrenergic receptor (B3AR), 5'-CTGCTAGCATCGAGACCTT and 3'-CGAGCATAGACGAAGAGCAT; carnitine palmitoyltransferase 1 (CPT1), 5'-ACCACTGGCCGAATGTCACAA and 3'-AGCG CGTAGCGCATGGTCAT; cytochrome C oxidase II (COX II), 5'-CGATTCCAACTTGGTCTACAA and 3'-GGAACCAT TTCTAGGACAATG; diacylglycerol acyltranferase (DGAT), 5'-TCCGCCTCTGGGCATTC and 3'-GAATCGGCCCAC AATCCA; fatty acid synthase (FAS), 5'-TGCTCCCAGCTGCAGGC and 3'-GCCCGGTAGCTCTGGGTGTA; glucose4-transporter (GLUT4), 5'-CTCAGCAGCGAGTGACTGGGAC and 3'-CCCTGAGTAGGCGCCAATGAGG; glycerol-3-phosphate acyltransferase (GPAT), 5'-CAGCTCT GCTGCCATCTTTG and 3'-TGCAGCTTCTGCAGGTACTCA; hormone sensitive lipase (HSL), 5'-GAAAAACA GCCTGTCGGACCA and 3'-CCAGGGCGATCTGCAGGT; insulin receptor (IR), 5'-GTAGCCTGATCATCAACATCCG and 3'-CCTGCCCATCAAACTCTGTCAC; insulin receptor substrate 1 (IRS1), 5'-CCTCTCCAACGCCAGAAGCTGCC and 3'-ATGGCGAGCCCTCCGGATACCG; insulin receptor substrate 2 (IRS2), 5'-GGATAATGGTGACTATACCGA GA and 3'-CTCACATCGATGGCGATATAGTT; lipoprotein lipase (LPL), 5'-AGGACCCCTGAAGACAC and 3'-GGCAC CCAACTCTCATA; peroxisome proliferator activated receptor alpha (PPAR $\alpha), 5$ '-TCCCTTGTAGCCTTTTGTCAT and 3'-AAGCCATTGCCGTACGCGAT; peroxisome proliferator activated receptor gamma (PPAR $\gamma$ ), 5'-AGGCCGAGAAGGAGAAGCTGTTG and 3'-TGGCCACCTCTTTG CTCTGCTC; PPAR $\gamma$ coactivator 1 (PGC-1), 5'-AAAGAATTCGAACTAAGGGATGGCGACTT and 3'-ATAGGATCCGGAATATGGTGATCGGGAAC; sterol regulatory element binding protein 1C (SREBP1C), 5'-GAGGCACTCCCCC AAAAGAT and 3'-TGATGAGAGGGAGGCCATTT; uncoupling protein 1 (UCP1), 5'-GATCCAAGGTGAAGGCC AGG and 3'-GTTGACAAGCTTTCTGTGG; uncoupling protein 2 (UCP2), 5'-GTGACCTGCTGCGCTGTGGTACT and 3'-GATCCAAGGGGAGAGTCA; housekeeping gene (beta actin), 5'-TGCTGTCCCTGTATGCCTCT and 3'-AGG TCTTTACGGATGTCACG

\section{Indirect Calorimetry, Body Composition and Serum Chemistries}

Metabolic measurements were assessed on a regular diet (at 9-10 weeks of age) and were obtained using an Oxymax (Columbus Instruments International Corp.) open circuit indirect calorimetry system as previously described [102]. The first $2 \mathrm{~h}$ was a period of adaptation for the animals, and metabolic rate $\left(\mathrm{VO}_{2}\right), \mathrm{RQ}$ (ratio of $\mathrm{VCO}_{2} / \mathrm{VO}_{2}$ ) and activity (counts) were then evaluated for a 72-h period. Energy expenditure was calculated as the product of calorific value of oxygen (calorific value of oxygen =
$3.815+1.232 \mathrm{RQ}$ ) and the volume of $\mathrm{O}_{2}$ consumed and this was normalized for body weight in kilograms. Two cohorts of male mice between 2-3 months of age ( $n=7-8$ mice of each genotype per cohort) were utilized for body composition, serum chemistry and metabolic cage analysis, carried out as described above and detailed previously [103].

\section{Data and Statistical Analysis}

Data are expressed as mean \pm SEM. Comparisons were performed using $t$ test or repeated-measures analysis of variance (ANOVA) where appropriate, using the programs Statview and Prism. P-values less than 0.05 were considered significant. For metabolic cage analysis, basal metabolic rate (BMR), defined as oxygen consumption during the light rest period, was determined by comparing $\mathrm{VO}_{2}$ measurements of $\mathrm{VGF}_{\mathrm{R}}$ knockout and wild-type littermates by two-tailed $t$-test. For real-time RT-PCR, assays were carried out in quadruplicate, and mean cycle threshold $\left(C_{t}\right)$ values $( \pm$ SEM) were compared by two-way ANOVA ( $\mathrm{p} \leq 0.05$ was considered significant). These values were used to calculate fold difference in mRNA levels $\left(2^{\Delta \Delta C t}\right)$.

\section{Authors' contributions}

EW carried out histological analysis, metabolic studies, real-time PCR experiments, and drafted the manuscript, SF carried out histological and EM analysis, morphometry, western blot analysis, and helped to draft the manuscript; HO carried out the metabolic and feeding analysis, whole mount $\beta$-galactosidase staining, and serum analysis; MS carried out the breeding and genotyping of VGFdeficient mice and assisted with histological, EM and western analysis; REG assisted with the design and coordination of the electron microscopic analysis; TC carried out the RIA analysis; MWS participated in the design and coordination of the study; SRS participated in the design and coordination of the study, and drafted the manuscript. All authors read and approved the final manuscript.

\section{Additional material}

\section{Additional file 1}

Supplemental Figure 1. Lipid deposition in multilocular cells of brown adipose tissue (BAT) and unilocular cells of white adipose tissue

(WAT) is reduced in VGF ${ }_{C 57}$ knockout mice. Representative sections of interscapular BAT (A-D) and epididymal WAT (E-F) from ad lib-fed

$\mathrm{Vgf}_{\mathrm{C} 57} /-(A, C$ and $E)$ and age-matched $\mathrm{Vgf}_{\mathrm{C} 57}+/+(B, D$, and $F)$ mice were stained with $H \& E$. The interscapular WAT that normally surrounds BAT in wild type mice (D) was absent in VGF-deficient mice (A and C). Adipocytes in interscapular BAT and epididymal WAT from $\mathrm{Vgf}_{\mathrm{C} 57}-/$ mice ( $A$ and $E$ ) contain less lipid accumulation than the corresponding adipocytes from wild type mice (B and F). Scale bars are $100 \mu \mathrm{m}$ in length.

Click here for file

[http://www.biomedcentral.com/content/supplementary/14726793-9-19-S1.pdf] 


\section{Additional file 2}

Supplemental Figure 2. Neonatal chemical sympathectomy with guanethidine (GE) increases fat and glycogen stores and plasma glucose levels in GE-treated VGF knockout mice. H\&E staining of liver, BAT, and epididymal WAT from 4 month-old $\mathrm{Vgf}_{\mathrm{C} 57}-/$ - mice treated daily with GE (50 mg/kg) or saline (control) from postnatal day 5 (P5) until P25, essentially as previously described $[104,105]$, which results in permanent sympathectomy. At 4 months of age, mice were anesthetized, blood samples collected, and glucose levels determined by glucometer; tissues were removed and formalin-fixed for histological analysis. Note that clear areas in liver, corresponding to glycogen deposits, are increased in GE-treated $\mathrm{Vgf}_{\mathrm{C} 57}-/$ - mice compared to saline-treated control $\mathrm{Vgf}_{\mathrm{C} 57} / /-$ mice (panels $A$ and $B$ ). BAT in GE-treated $\mathrm{Vgf}_{\mathrm{C} 57}-/$ - mice is bordered by WAT (arrows), which is reduced in saline-treated $\mathrm{Vgf}_{\mathrm{C} 57}-/$ - mice (panels $C$ and $D)$. Fat storage is reduced in WAT from saline-treated compared to GE-treated $\mathrm{Vgf}_{\mathrm{C} 57}-/$ - mice (panels E and F). Scale bars are $100 \mu \mathrm{m}$ in length. GE-treatment significantly increased circulating glucose levels in $\mathrm{Vgf}_{\mathrm{C} 57}-/-$ but not in $\mathrm{Vgf}_{\mathrm{C} 57}+/$ - mice compared to their respective salinetreated controls (panel G; ANOVA, $p<0.05$, mean \pm SEM).

Click here for file

[http://www.biomedcentral.com/content/supplementary/14726793-9-19-S2.pdf]

\section{Additional file 3}

Supplemental Figure 3. Immunohistochemical localization of VGF protein in BAT. Immunohistochemical staining of BAT with anti-VGF and anti-tyrosine hydroxylase (TH) antisera in wild-type mice was carried out, and showed similar patterns. Sections were stained with rabbit anti$V_{G F_{78-340}}$ [98] (panels $A, C$, and D) and anti-TH (Chemicon International, Temecula, CA) (panel B) (in panels $A$ and B, arrows point to VGF positive and TH positive fibers, respectively). Note that VGF immunoreactivity is also seen in the adventitia of small arterioles (panel C; arrows). In addition, VGF-positive puncta in direct contact with the brown adipocyte (panel D) were visualized using immunofluorescent staining. Scale bars are $100 \mu \mathrm{m}$ (panels A-C) and $10 \mu \mathrm{m}$ (panel D).

Click here for file

[http://www.biomedcentral.com/content/supplementary/14726793-9-19-S3.pdf]

\section{Acknowledgements}

Supported in part by NIH Endocrine Training Grant 5T32DK07645 (EW and SF), ROI DK07I 308 (SRS), ROI DK57702 (SRS), the American Heart Association (SRS), and the Diabetes Action Research and Education Foundation (SRS). SRS is a NARSAD van Ameringen Investigator. We thank Carla Montgomery and Heather Bell for technical assistance, and Dr. Susan Morgello and Noreen Mall in the Mount Sinai Shared Research Facility Histology Service for assistance with the adipose tissue analysis.

\section{References}

I. Barsh G: From Agouti to Pomc-- 100 years of fat blonde mice. Nat Med 1999, 5(9):984-985.

2. Song CK, Jackson RM, Harris RB, Richard D, Bartness TJ: Melanocortin-4 receptor mRNA is expressed in sympathetic nervous system outflow neurons to white adipose tissue. Am J Physiol Regul Integr Comp Physiol 2005, 289(5):R I 467-| 476.

3. Voss-Andreae A, Murphy JG, Ellacott KL, Stuart RC, Nillni EA, Cone $R D$, Fan W: Role of the central melanocortin circuitry in adaptive thermogenesis of brown adipose tissue. Endocrinology 2007, I48(4): I550-I560.

4. Elmquist JK, Maratos-Flier E, Saper CB, Flier JS: Unraveling the central nervous system pathways underlying responses to leptin. Nat Neurosci 1998, I(6):445-450.
5. Kishi T, Aschkenasi CJ, Lee CE, Mountjoy KG, Saper CB, Elmquist JK: Expression of melanocortin 4 receptor mRNA in the central nervous system of the rat. J Comp Neurol 2003, 457(3):2/3-235.

6. Bray GA, York DA: The MONA LISA hypothesis in the time of leptin. Recent Prog Horm Res 1998, 53:95-1 17. discussion II7-II8

7. Friedman JM, Halaas JL: Leptin and the regulation of body weight in mammals. Nature 1998, 395(6704):763-770.

8. Fan W, Dinulescu DM, Butler AA, Zhou J, Marks DL, Cone RD: The central melanocortin system can directly regulate serum insulin levels. Endocrinology 2000, I 41(9):3072-3079.

9. Li G, Mobbs CV, Scarpace PJ: Central pro-opiomelanocortin gene delivery results in hypophagia, reduced visceral adiposity, and improved insulin sensitivity in genetically obese Zucker rats. Diabetes 2003, 52(8): $195 \mathrm{I}-1957$.

10. Ricquier D: Fundamental mechanisms of thermogenesis. $C R$ Biol 2006, 329(8):578-586. discussion 653-575

II. Brito MN, Brito NA, Baro DJ, Song CK, Bartness TJ: Differential activation of the sympathetic innervation of adipose tissues by melanocortin receptor stimulation. Endocrinology 2007, I 48( I I ):5339-5347.

12. Collins S, Daniel KW, Petro AE, Surwit RS: Strain-specific response to beta 3-adrenergic receptor agonist treatment of diet-induced obesity in mice. Endocrinology 1997, I38(I):405-4I3.

13. Cousin B, Cinti S, Morroni M, Raimbault S, Ricquier D, Penicaud L, Casteilla L: Occurrence of brown adipocytes in rat white adipose tissue: molecular and morphological characterization. J Cell Sci 1992, I03(Pt 4):93I-942.

14. Ghorbani M, Himms-Hagen J: Appearance of brown adipocytes in white adipose tissue during CL 316,243 -induced reversal of obesity and diabetes in Zucker fa/fa rats. Int J Obes Relat Metab Disord 1997, 2 I (6):465-475.

15. Guerra C, Koza RA, Yamashita H, Walsh K, Kozak LP: Emergence of brown adipocytes in white fat in mice is under genetic control. Effects on body weight and adiposity. J Clin Invest 1998, I02(2):412-420.

16. Xue B, Coulter A, Rim JS, Koza RA, Kozak LP: Transcriptional synergy and the regulation of UcpI during brown adipocyte induction in white fat depots. Mol Cell Biol 2005, 25( I 8):83। I-8322.

17. Hahm S, Fekete C, Mizuno TM, Windsor J, Yan H, Boozer CN, Lee C, Elmquist JK, Lechan RM, Mobbs CV, et al.: VGF is required for obesity induced by diet, gold thioglucose treatment and agouti, and is differentially regulated in POMC- and NPYcontaining arcuate neurons in response to fasting. J Neurosci 2002, 22:6929-6938.

18. Watson E, Hahm S, Mizuno TM, Windsor J, Montgomery C, Scherer PE, Mobbs CV, Salton SR: VGF ablation blocks the development of hyperinsulinemia and hyperglycemia in several mouse models of obesity. Endocrinology 2005, I46(I 2):5|5|-5|63.

19. Salton SR, Ferri GL, Hahm S, Snyder SE, Wilson AJ, Possenti R, Levi $A$ : VGF: a novel role for this neuronal and neuroendocrine polypeptide in the regulation of energy balance. Front $\mathrm{Neu}-$ roendocrinol 2000, 21 (3): 199-219.

20. Levi A, Ferri GL, Watson E, Possenti R, Salton SR: Processing, distribution and function of VGF, a neuronal and endocrine peptide precursor. Cell Mol Neurobiol 2004, 24:517-533.

21. Hahm S, Mizuno TM, Wu TJ, Wisor JP, Priest CA, Kozak CA, Boozer CN, Peng B, McEvoy RC, Good P, et al.: Targeted deletion of the Vgf gene indicates that the encoded secretory peptide precursor plays a novel role in the regulation of energy balance. Neuron 1999, 23(3):537-548.

22. Bergen HT, Mizuno TM, Taylor J, Mobbs CV: Hyperphagia and weight gain after gold-thioglucose: relation to hypothalamic neuropeptide $Y$ and proopiomelanocortin. Endocrinology 1998, I 39(II):4483-4488.

23. Morris MJ, Tortelli CF, Filippis A, Proietto J: Reduced BAT function as a mechanism for obesity in the hypophagic, neuropeptide $Y$ deficient monosodium glutamate-treated rat. Regul Pept 1998, 75-76:44|-447.

24. Tsukahara F, Uchida Y, Ohba K, Ogawa A, Yoshioka T, Muraki T: The effect of acute cold exposure and norepinephrine on uncoupling protein gene expression in brown adipose tissue of monosodium glutamate- obese mice. Jpn J Pharmacol 1998, 77(3):247-249

25. Valenzuela DM, Murphy AJ, Frendewey D, Gale NW, Economides AN, Auerbach W, Poueymirou WT, Adams NC, Rojas J, Yasenchak J, 
et al.: High-throughput engineering of the mouse genome coupled with high-resolution expression analysis. Nat Biotechnol 2003, 2 I (6):652-659.

26. Shi H, Strader AD, Woods SC, Seeley RJ: The effect of fat removal on glucose tolerance is depot specific in male and female mice. Am J Physiol Endocrinol Metab 2007, 293(4): EIOI2-1020.

27. Ferre P, Foufelle F: SREBP-I c Transcription Factor and Lipid Homeostasis: Clinical Perspective. Horm Res 2007, 68(2):72-82

28. Krauss $S$, Zhang CY, Lowell BB: The mitochondrial uncouplingprotein homologues. Nat Rev Mol Cell Biol 2005, 6(3):248-26I.

29. Affourtit C, Crichton PG, Parker N, Brand MD: Novel uncoupling proteins. Novartis Found Symp 2007, 287:70-80. discussion 80-91

30. Echtay KS: Mitochondrial uncoupling proteins--what is their physiological role? Free Radic Biol Med 2007, 43(10): |35|-|37|.

31. Collins S, Daniel KW, Rohlfs EM, Ramkumar V, Taylor IL, Gettys TW: Impaired expression and functional activity of the beta 3 and beta $\mathrm{I}$ - adrenergic receptors in adipose tissue of congenitally obese (C57BL/6) ob/ob) mice. Mol Endocrinol 1994, 8(4):5। 8-527.

32. Susulic VS, Frederich RC, Lawitts J, Tozzo E, Kahn BB, Harper ME, Himms-Hagen J, Flier JS, Lowell BB: Targeted disruption of the beta 3-adrenergic receptor gene. I Biol Chem 1995 270(49):29483-29492.

33. Cannon B, Nedergaard J, Lundberg JM, Hokfelt T, Terenius L, Goldstein M: 'Neuropeptide tyrosine' (NPY) is co-stored with noradrenaline in vascular but not in parenchymal sympathetic nerves of brown adipose tissue. Exp Cell Res 1986, 164(2):546-550

34. Lever JD, Mukherjee S, Norman D, Symons D, Jung RT: Neuropeptide and noradrenaline distributions in rat interscapular brown fat and in its intact and obstructed nerves of supply. Auton Nerv Syst 1988, 25(I): 15-25.

35. Norman D, Mukherjee S, Symons D, Jung RT, Lever JD: Neuropeptides in interscapular and perirenal brown adipose tissue in the rat: a plurality of innervation. I Neurocytol 1988 I 7(3):305-3II.

36. Mukherjee S, Lever JD, Norman D, Symons D, Spriggs TL, Jung RT: A comparison of the effects of 6-hydroxydopamine and reserpine on noradrenergic and peptidergic nerves in rat brown adipose tissue. J Anat 1989, 167:189-193.

37. De Matteis R, Ricquier D, Cinti S: TH-, NPY-, SP-, and CGRPimmunoreactive nerves in interscapular brown adipose tissue of adult rats acclimated at different temperatures: an immunohistochemical study. J Neurocytol 1998, 27( I 2):877-886.

38. Chakraborty TR, Tkalych O, Nanno D, Garcia AL, Devi LA, Salton SR: Quantification of VGF- and pro-SAAS-derived peptides in endocrine tissues and the brain, and their regulation by diet and cold stress. Brain Res 2006, I089(I):2I-32.

39. Cinti S: Adipose tissues and obesity. Ital ] Anat Embryol 1999 104(2):37-51.

40. Cinti $\mathrm{S}$ : The role of brown adipose tissue in human obesity. Nutr Metab Cardiovasc Dis 2006, 16(8):569-574.

4I. Shinozaki K, Shimizu Y, Shiina T, Nishijima K, Atoji Y, Nikami H, Niijima A, Takewaki T: A neurophysiological evidence of capsaicinsensitive nerve components innervating interscapular brown adipose tissue. Auton Neurosci 2005, I I 9(I): 16-24

42. Bradley RL, Mansfield JP, Maratos-Flier E: Neuropeptides, including neuropeptide $\mathbf{Y}$ and melanocortins, mediate lipolysis in murine adipocytes. Obes Res 2005, I3(4):653-66I.

43. Kuo LE, Kitlinska JB, Tilan JU, Li L, Baker SB, Johnson MD, Lee EW Burnett MS, Fricke ST, Kvetnansky R, et al.: Neuropeptide $\mathbf{Y}$ acts directly in the periphery on fat tissue and mediates stressinduced obesity and metabolic syndrome. Nat Med 2007, | 3(7):803-8I I.

44. Ruohonen ST, Pesonen U, Moritz N, Kaipio K, Roytta M, Koulu M, Savontaus E: Transgenic Mice Overexpressing Neuropeptide $\mathbf{Y}$ in Noradrenergic Neurons: A Novel Model of Increased Adiposity and Impaired Glucose Tolerance. Diabetes 2008, 57(6):1517-1525.

45. Kos K, Harte AL, James S, Snead DR, O'Hare JP, McTernan PG, Kumar S: Secretion of neuropeptide $Y$ in human adipose tissue and its role in maintenance of adipose tissue mass. $\mathrm{Am}$ Physiol Endocrinol Metab 2007, 293(5): EI 335 - I 340.

46. Yang K, Guan H, Arany E, Hill DJ, Cao X: Neuropeptide $Y$ is produced in visceral adipose tissue and promotes proliferation of adipocyte precursor cells via the $Y I$ receptor. FASEB J 2008, 22(7):2452-2464
47. Sudo M, Minokoshi Y, Shimazu T: Ventromedial hypothalamic stimulation enhances peripheral glucose uptake in anesthetized rats. Am J Physiol I99I, 26 I (3 Pt I):E298-303.

48. Langin $D$, Lucas $S$, Lafontan M: Millennium fat-cell lipolysis reveals unsuspected novel tracks. Horm Metab Res 2000, 32(I I12):443-452.

49. Liu CY, Liang LC, Chang LC: Differential responses of hormonesensitive lipase gene to nutritional transition in adipose tissue, liver, and skeletal muscle of pigs. Biochem Mol Biol Int 1995, 36(3):689-694

50. Li Y, Bujo H, Takahashi K, Shibasaki M, Zhu Y, Yoshida Y, Otsuka Y, Hashimoto N, Saito $Y$ : Visceral fat: higher responsiveness of fat mass and gene expression to calorie restriction than subcutaneous fat. Exp Biol Med (Maywood) 2003, 228( I0): I I I 8- I I 23.

5I. Bertile F, Criscuolo F, Oudart H, Le Maho Y, Raclot T: Differences in the expression of lipolytic-related genes in rat white adipose tissues. Biochem Biophys Res Commun 2003, 307(3):540-546.

52. Jocken JW, Langin D, Smit E, Saris WH, Valle C, Hul GB, Holm C, Arner P, Blaak EE: Adipose triglyceride lipase and hormonesensitive lipase protein expression is decreased in the obese insulin-resistant state. I Clin Endocrinol Metab 2007, 92(6):2292-2299

53. Sukonina V, Lookene A, Olivecrona T, Olivecrona G: Angiopoietinlike protein 4 converts lipoprotein lipase to inactive monomers and modulates lipase activity in adipose tissue. Proc Nat Acad Sci USA 2006, 103(46): 17450-17455.

54. Kageyama H, Hirano T, Okada K, Ebara T, Kageyama A, Murakami T, Shioda S, Adachi M: Lipoprotein lipase mRNA in white adipose tissue but not in skeletal muscle is increased by pioglitazone through PPAR-gamma. Biochem Biophys Res Commun 2003, 305(I):22-27.

55. Laplante M, Sell H, MacNaul KL, Richard D, Berger JP, Deshaies $Y$ : PPAR-gamma activation mediates adipose depot-specific effects on gene expression and lipoprotein lipase activity: mechanisms for modulation of postprandial lipemia and differential adipose accretion. Diabetes 2003, 52(2):29|-299.

56. Schoonjans K, Peinado-Onsurbe J, Lefebvre AM, Heyman RA, Briggs M, Deeb S, Staels B, Auwerx J: PPARalpha and PPARgamma activators direct a distinct tissue-specific transcriptional response via a PPRE in the lipoprotein lipase gene. Embo J 1996, I5(19):5336-5348.

57. Kuusela P, Jacobsson A, Klingenspor M, Rehnmark S, Heldmaier G, Cannon B, Nedergaard J: Contrasting adrenergic effects on lipoprotein lipase gene expression in the brown adipose tissue of intact mice and in cultured brown adipocytes from mice. Biochim Biophys Acta 1997, 1345(3):327-337.

58. Uldry M, Yang W, St-Pierre J, Lin J, Seale P, Spiegelman BM: Complementary action of the PGC-I coactivators in mitochondrial biogenesis and brown fat differentiation. Cell Metab 2006, 3(5):333-341.

59. Griggio MA: The participation of shivering and nonshivering thermogenesis in warm and cold-acclimated rats. Comp Biochem Physiol A 1982, 73(3):48I-484.

60. Sell H, Berger JP, Samson P, Castriota G, Lalonde J, Deshaies Y, Richard D: Peroxisome proliferator-activated receptor gamma agonism increases the capacity for sympathetically mediated thermogenesis in lean and ob/ob mice. Endocrinology 2004, I 45(8):3925-3934

61. Hamilton JM, Mason PW, McElroy JF, Wade GN: Dissociation of sympathetic and thermogenic activity in brown fat of Syrian hamsters. Am J Physiol 1986, 250(3 Pt 2):R389-395.

62. McElroy JF, Wade GN: Short photoperiod stimulates brown adipose tissue growth and thermogenesis but not norepinephrine turnover in Syrian hamsters. Physiol Behav 1986, 37(2):307-3II.

63. Sigurdson SL, Himms-Hagen J: Control of norepinephrine turnover in brown adipose tissue of Syrian hamsters. Am J Physiol 1988, 254(6 Pt 2):R960-968.

64. Giordano A, Frontini A, Murano I, Tonello C, Marino MA, Carruba MO, Nisoli E, Cinti S: Regional-dependent increase of sympathetic innervation in rat white adipose tissue during prolonged fasting. J Histochem Cytochem 2005, 53(6):679-687.

65. Penn DM, Jordan LC, Kelso EW, Davenport JE, Harris RB: Effects of central or peripheral leptin administration on norepinephrine turnover in defined fat depots. Am J Physiol Regul Integr Comp Physiol 2006, 29 I(6):R I6I3-162I.

66. Watson E: VGF: A regulator of energy and glucose homeostasis. Understanding VGF's mechanism of action in modulat- 
ing autonomic homeostasis. In PhD Dissertation Mount Sinai School of Medicine of New York University; 2006.

67. Gautam D, Gavrilova O, Jeon J, Pack S, Jou W, Cui Y, Li JH, Wess J: Beneficial metabolic effects of M3 muscarinic acetylcholine receptor deficiency. Cell Metab 2006, 4(5):363-375.

68. van Baak MA: The peripheral sympathetic nervous system in human obesity. Obes Rev 200I, 2(I):3-14.

69. Landsberg $L$ : Feast or famine: the sympathetic nervous system response to nutrient intake. Cell Mol Neurobiol 2006, 26(46):497-508.

70. Tentolouris N, Liatis S, Katsilambros N: Sympathetic system activity in obesity and metabolic syndrome. Ann N Y Acad Sc 2006, 1083:129-152.

71. Ahima RS: Adipose tissue as an endocrine organ. Obesity (Silver Spring) 2006, I 4(Suppl 5):242S-249S.

72. Campfield LA, Smith FJ, Guisez Y, Devos R, Burn P: Recombinant mouse $O B$ protein: evidence for a peripheral signal linking adiposity and central neural networks. Science 1995, 269(5223):546-549.

73. Halaas JL, Gajiwala KS, Maffei M, Cohen SL, Chait BT, Rabinowitz D, Lallone RL, Burley SK, Friedman JM: Weight-reducing effects of the plasma protein encoded by the obese gene. Science 1995, 269(5223):543-546.

74. Pelleymounter MA, Cullen MJ, Baker MB, Hecht R, Winters D, Boone $T$, Collins $F$ : Effects of the obese gene product on body weight regulation in ob/ob mice. Science 1995, 269(5223):540-543.

75. Dobbins RL, Szczepaniak LS, Zhang W, McGarry JD: Chemical sympathectomy alters regulation of body weight during prolonged ICV leptin infusion. Am J Physiol Endocrinol Metab 2003, 284(4):E778-787.

76. Balthasar N, Dalgaard LT, Lee CE, Yu J, Funahashi H, Williams T, Ferreira M, Tang V, McGovern RA, Kenny CD, et al.: Divergence of melanocortin pathways in the control of food intake and energy expenditure. Cell 2005, I 23(3):493-505.

77. Butler AA, Marks DL, Fan W, Kuhn CM, Bartolome M, Cone RD: Melanocortin-4 receptor is required for acute homeostatic responses to increased dietary fat. Nat Neurosci 200I, 4(6):605-6II.

78. Schaak S, Mialet-Perez J, Flordellis C, Paris $\mathrm{H}$ : Genetic variation of human adrenergic receptors: from molecular and functional properties to clinical and pharmacogenetic implications. Curr Top Med Chem 2007, 7(2):217-231.

79. Bachman ES, Dhillon H, Zhang CY, Cinti S, Bianco AC, Kobilka BK, Lowell $B B$ : betaAR signaling required for diet-induced thermogenesis and obesity resistance. Science 2002 297(5582):843-845

80. Jimenez M, Leger B, Canola K, Lehr L, Arboit P, Seydoux J, Russell AP Giacobino JP, Muzzin P, Preitner F: Beta(1)/beta(2)/beta(3)adrenoceptor knockout mice are obese and cold-sensitive but have normal lipolytic responses to fasting. FEBS Lett 2002 , 530(I-3):37-40

81. Demas GE, Bartness TJ: Direct innervation of white fat and adrenal medullary catecholamines mediate photoperiodic changes in body fat. Am J Physiol Regul Integr Comp Physiol 200I, 28 I(5):R I 499-I 505

82. Demas GE, Bowers RR, Bartness TJ, Gettys TW: Photoperiodic regulation of gene expression in brown and white adipose tissue of Siberian hamsters (Phodopus sungorus). Am J Physiol Regul Integr Comp Physiol 2002, 282(I):R I I4-I2I.

83. Tavernier G, Jimenez M, Giacobino JP, Hulo N, Lafontan M, Muzzin P, Langin D: Norepinephrine induces lipolysis in betal/beta2/ beta3-adrenoceptor knockout mice. Mol Pharmacol 2005, 68(3):793-799.

84. Ste Marie L, Luquet S, Curtis W, Palmiter RD: Norepinephrineand epinephrine-deficient mice gain weight normally on a high-fat diet. Obes Res 2005, 13(9): $1518-1522$

85. Salton SR, Fischberg DJ, Dong KW: Structure of the gene encoding VGF, a nervous system-specific mRNA that is rapidly and selectively induced by nerve growth factor in $\mathrm{PCI} 2$ cells. Mol Cell Biol I99I, II(5):2335-2349.

86. Snyder SE, Pintar JE, Salton SR: Developmental expression of VGF mRNA in the prenatal and postnatal rat. J Comp Neurol 1998, 394(I):64-90.

87. Chan MY, Zhao Y, Heng CK: Sequential responses to high-fat and high-calorie feeding in an obese mouse model. Obesity (Silver Spring) 2008, 16(5):972-978.
88. Lin S, Thomas TC, Storlien LH, Huang XF: Development of high fat diet-induced obesity and leptin resistance in C57BI/6J mice. Int J Obes Relat Metab Disord 2000, 24(5):639-646.

89. Mastaitis J: Regulation of hypothalamic gene expression during hypoglycemia and low-carbohydrate diets. Ph.D. Dissertation, Graduate School of Biological Sciences, Mount Sinai School of Medicine 2007:I-I36.

90. Bartolomucci A, La Corte G, Possenti R, Locatelli V, Rigamonti AE, Torsello A, Bresciani E, Bulgarelli I, Rizzi R, Pavone F, et al.: TLQP. 2I, a VGF-derived peptide, increases energy expenditure and prevents the early phase of diet-induced obesity. Proc Natl Acad Sci USA 2006, 103(39): | 4584- 14589.

9I. Jethwa P, Warner A, Nilaweera K, Brameld J, Keyte J, Carter W, Bolton N, Bruggraber M, Morgan P, Barrett P, et al.: VGF-derived peptide, TLQP-2I, regulates food intake and body weight in Siberian hamsters. Endocrinology 2007, 148(8):4044-4055.

92. Trani E, Ciotti T, Rinaldi AM, Canu N, Ferri GL, Levi A, Possenti R: Tissue-specific processing of the neuroendocrine protein VGF. J Neurochem 1995, 65(6):244I-2449.

93. Trani E, Giorgi A, Canu N, Amadoro G, Rinaldi AM, Halban PA, Ferri GL, Possenti R, Schinina ME, Levi A: Isolation and characterization of VGF peptides in rat brain. Role of $P C I / 3$ and $P C 2$ in the maturation of VGF precursor. I Neurochem 2002, 8 I (3):565-574.

94. Bartolomucci A, Possenti R, Levi A, Pavone F, Moles A: The role of the vgf gene and VGF-derived peptides in nutrition and metabolism. Genes Nutr 2007, 2:169-|80.

95. Bozdagi O, Rich E, Tronel S, Sadahiro M, Patterson K, Shapiro ML, Alberini CM, Huntley GW, Salton SR: The neurotrophin-inducible gene Vgf regulates hippocampal function and behavior through a brain-derived neurotrophic factor-dependent mechanism. J Neurosci 2008, 28(39):9857-9869.

96. Severini C, Ciotti MT, Biondini L, Quaresima S, Rinaldi AM, Levi A, Frank C, Possenti R: TLQP-2I, a neuroendocrine VGF-derived peptide, prevents cerebellar granule cells death induced by serum and potassium deprivation. I Neurochem 2008, 104(2):534-544.

97. Severini C, La Corte G, Improta G, Broccardo M, Agostini S, Petrella C, Sibilia V, Pagani F, Guidobono F, Bulgarelli I, et al.: In vitro and in vivo pharmacological role of TLQP-2I, a VGF-derived peptide, in the regulation of rat gastric motor functions. BrJ Pharmacol 2009, I57(6):984-993.

98. Salton SR, Volonte C, D'Arcangelo G: Stimulation of vgf gene expression by NGF is mediated through multiple signal transduction pathways involving protein phosphorylation. FEBS Lett 1995, 360(2): 106-110.

99. Fields-Berry SC, Halliday AL, Cepko CL: A recombinant retrovirus encoding alkaline phosphatase confirms clonal boundary assignment in lineage analysis of murine retina. Proc Natl Acad Sci USA 1992, 89(2):693-697.

100. Fire A: Histochemical techniques for locating Escherichia coli beta-galactosidase activity in transgenic organisms. Genet Anal Tech Appl 1992, 9(5-6): I5I-158.

I0I. Mzhavia N, Berman Y, Che FY, Fricker LD, Devi LA: ProSAAS processing in mouse brain and pituitary. J Biol Chem 200I, 276(9):6207-6213

102. Sleeman MW, Garcia K, Liu R, Murray JD, Malinova L, Moncrieffe M, Yancopoulos GD, Wiegand SJ: Ciliary neurotrophic factor improves diabetic parameters and hepatic steatosis and increases basal metabolic rate in $\mathbf{d b} / \mathbf{d b}$ mice. Proc Natl Acad Sci USA 2003, I00(24): | 4297-14302.

103. Wortley KE, Garcia K, Okamoto H, Thabet K, Anderson KD, Shen V, Herman JP, Valenzuela D, Yancopoulos GD, Tschop MH, et al.: Peptide $\mathrm{YY}$ regulates bone turnover in rodents. Gastroenterology 2007, I 33(5): | 534- I543.

104. Johnson EM Jr, Cantor E, Douglas JR Jr: Biochemical and functional evaluation of the sympathectomy produced by the administration of guanethidine to newborn rats. J Pharmacol Exp Ther 1975, 193(2):503-5।2.

105. Demas GE, Bartness T]: Novel method for localized, functional sympathetic nervous system denervation of peripheral tissue using guanethidine. J Neurosci Methods 200 I, I I 2(I):2 I-28. 